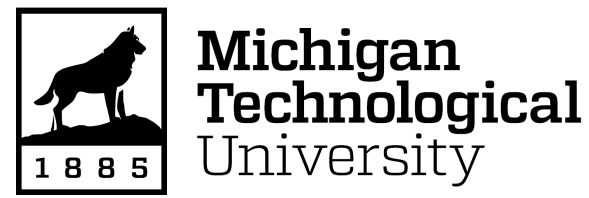

Michigan Technological University Digital Commons @ Michigan Tech

2017

\title{
THE EFFECTS OF EARLY PRUNING ON THE NEAR-GROUND BRANCH DENSITY OF FOUR LIVE FENCING SPECIES
}

Aric Devens

Michigan Technological University, awdevens@mtu.edu

Copyright 2017 Aric Devens

\section{Recommended Citation}

Devens, Aric, "THE EFFECTS OF EARLY PRUNING ON THE NEAR-GROUND BRANCH DENSITY OF FOUR LIVE FENCING SPECIES", Open Access Master's Thesis, Michigan Technological University, 2017.

https://doi.org/10.37099/mtu.dc.etdr/421

Follow this and additional works at: https://digitalcommons.mtu.edu/etdr

Part of the Agricultural Science Commons, Other Environmental Sciences Commons, Other Forestry and Forest Sciences Commons, Other Plant Sciences Commons, and the Sustainability Commons 
THE EFFECTS OF EARLY PRUNING ON THE NEAR-GROUND BRANCH DENSITY OF FOUR LIVE FENCING SPECIES

\title{
By
}

Aric W. Devens

\begin{abstract}
A THESIS
Submitted in partial fulfillment of the requirements for the degree of MASTER OF SCIENCE

In Forestry

MICHIGAN TECHNOLOGICAL UNIVERSITY

2017
\end{abstract}

(C) 2017 Aric W. Devens 
This thesis has been approved in partial fulfillment of the requirements for the Degree of MASTER OF SCIENCE in Forestry.

School of Forest Resources and Environmental Science

Thesis Advisor: Audrey L. Mayer

Committee Member: Molly A. Cavaleri

Committee Member: Christopher R. Webster

School Dean: Terry Sharik 


\section{Table of Contents}

List of figures ................................................................................................................

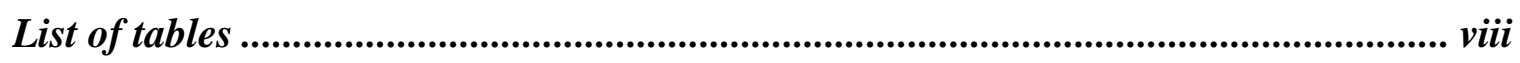

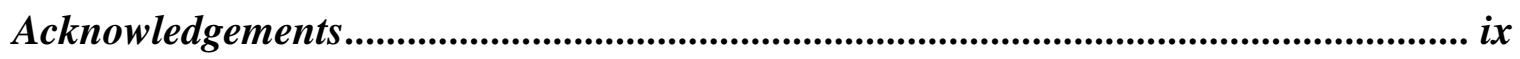

Abstract

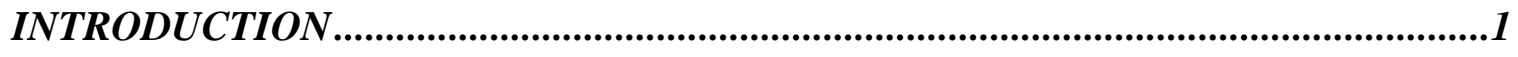

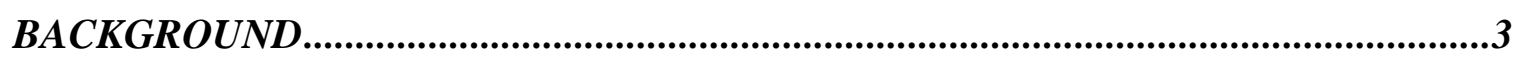

Agriculture in Senegal............................................................... 3

Migratory Pastoralism .......................................................... 3

Local Herds .......................................................................... 6

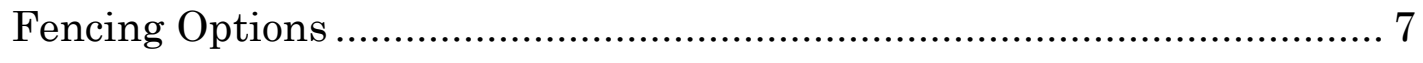

Thorny Hedges ................................................................... 9

Research Direction .......................................................... 10

METHODS...............................................................................................................14

Site Description................................................................ 14

Variables Investigated ........................................................ 15

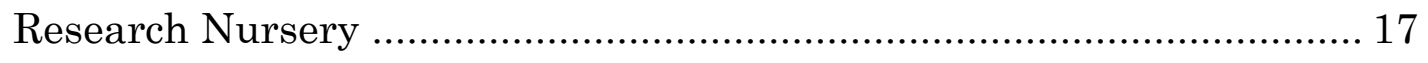

Planting Site ........................................................................ 19

Treatment Application................................................................ 21

Data Collection and Analysis ............................................... 21 
RESULTS

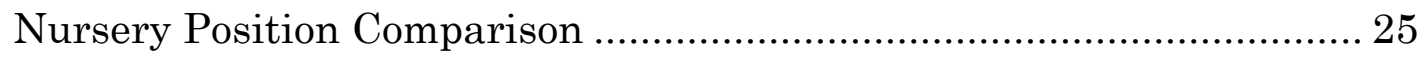

Interaction Between Variables............................................................ 26

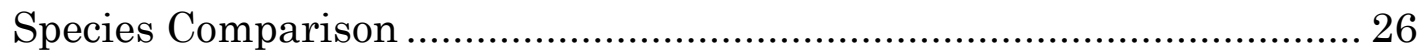

Stems Below 35cm - In the Nursery ……................................ 26

Species Comparison - After one Season ....................................... 27

Pruning Treatments Comparison by Species ...................................... 28

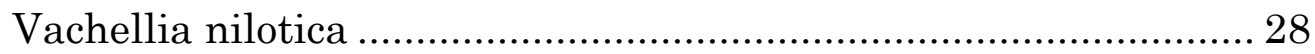

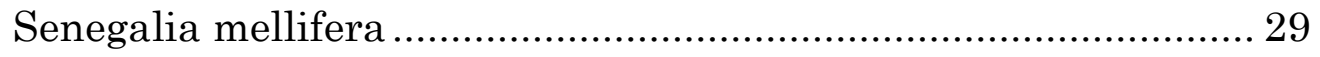

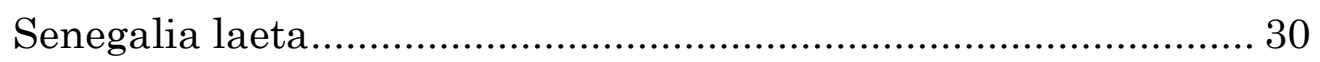

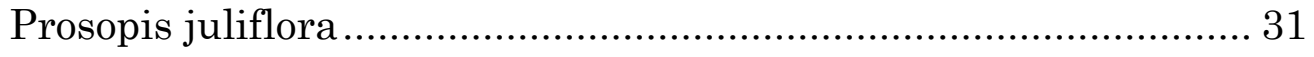

DISCUSSION

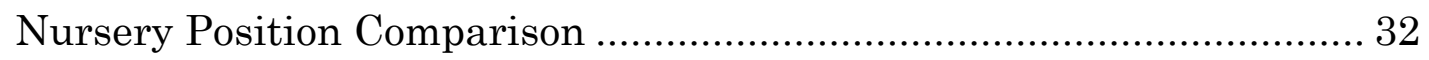

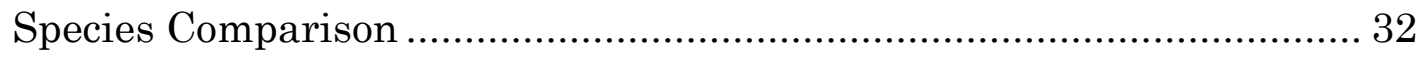

Pruning Treatments Comparison ....................................................... 34

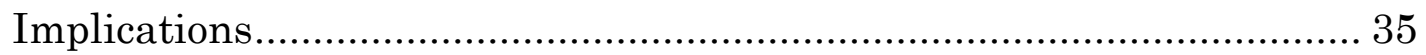

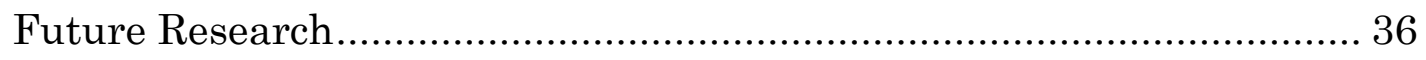

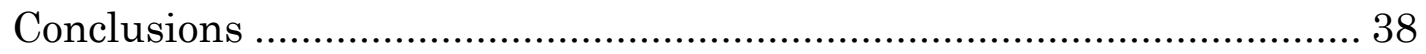


Appendix A - Layout of the Research Fence ...................................................................45

Appendix B - Copyright Documentation .......................................................................46

Appendix C - Steps Used In Processing the Photo Data...........................................47 


\section{List of figures}

Figure 1. A large migrating herd and a small local herd ............................... 7

Figure 2. Effective and ineffective thorny hedges ....................................... 11

Figure 3. Location of Senegal within Africa, and the study site, Dialakoto,

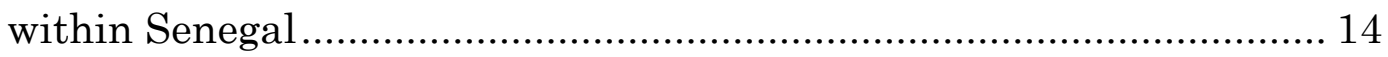

Figure 4. The experimental treatments applied......................................... 16

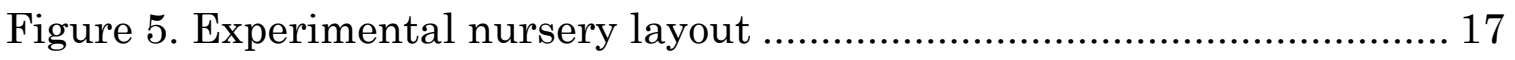

Figure 6. The assignment of position number within the nursery................ 18

Figure 7. The author seeding the experimental nursery, with V. nilotica

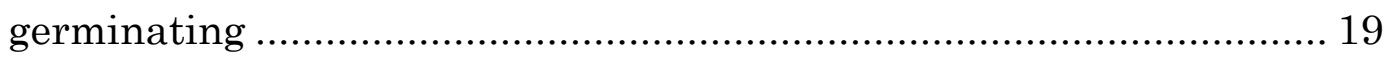

Figure 8. The stages of processing the photographic data ............................ 22

Figure 9. Mean stems below $35 \mathrm{~cm}$ at the time of out-planting, by position in

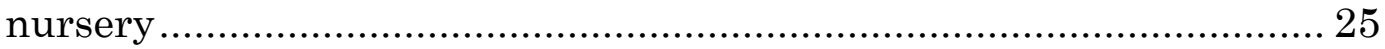

Figure 10. Graph of species comparison results for the three metrics measured 25

Figure 11. Summary graph of the three metrics comparing treatments within

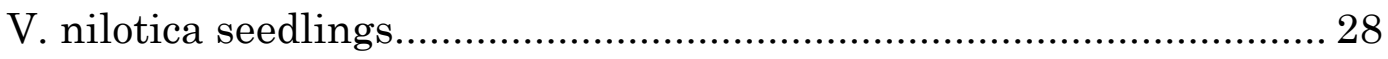

Figure 12. Summary graph of the three metrics comparing treatments within

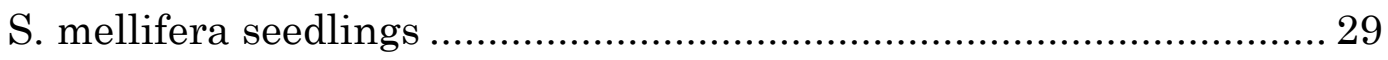

Figure 13. Summary graph of the three metrics comparing treatments within

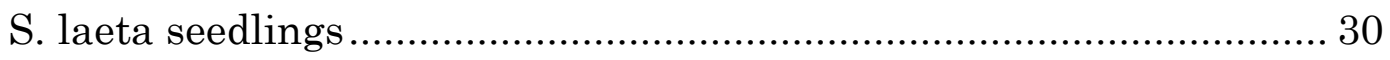


Figure 14. Summary graph of the three metrics comparing treatments within

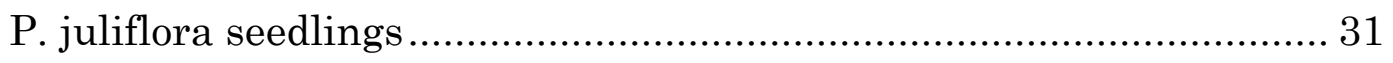

Figure 15. Average individuals of each species from the research fence ....... 33 


\section{List of tables}

Table 1. Sample sizes for the nursery data analysis.............................. 24

Table 2. Sample sizes for the data collected after one season of growth ....... 24

Table 3. MANOVA results for the metrics investigated ............................. 26

Table 4. Mean stems below $35 \mathrm{~cm}$ at the time of out-planting, by species..... 26 


\section{Acknowledgements}

Firstly, I wish to thank my Advisor, Dr. Audrey Mayer, for her support, patience, and responsiveness to my questions. Thanks also to my thesis committee, Dr. Molly Cavaleri and Dr. Cristopher Webster, for their critique and advice. Dr. Blair Orr has a wealth of knowledge regarding Peace Corps and PCMI research which he was never shy to share; his advice and support was greatly appreciated throughout my time at Michigan Tech. Dr. Kari Henquinet has also been a great source of advice and support; and her visits to Senegal were always a welcome respite. I owe Mike Hyslop for his technical savvy and taking the time to give me invaluable help in processing the photo data.

On the Senegal side, I wish to thank Kelly Kurz and Todd Martin Buchkovich for their invaluable labor helping to install the research fence. Thanks to Badembo DRAME for his willingness to let me experiment on his land. I owe a great debt to all the Peace Corps Senegal staff who supported me during my service. In particular, I wish to thank the technical staff who imparted on me great knowledge and advice: Famara MASSALY, Demba SIDIBE, Youssoupha BOYE, Cherif DJITTE, Arfang SADIO, and Abibou SANE.

I never could have accomplished any of my work in Dialakoto without my counterpart and friend Ousmane BATE who supported me in all aspects throughout my time there, and who passed away shortly before this thesis was finalized.

Finally, I owe an infinite debt to my wife, Gwendolyn Jacobson, for her help, guidance, patience, and support. Without her I probably never would have accomplished what things I have. 


\begin{abstract}
Crop losses in home gardens greatly impact the wellbeing of rural West African families. Herbivory by migratory or local livestock represents a significant source of crop loss. Live-fencing gardens with thorny hedges is a low-cost and sustainable strategy for reducing losses due to herbivory. However, guidance on the establishment of thorny hedges is inconsistent, poorly publicized, and often anecdotal. Therefore, this study evaluated the effects of three early pruning treatments on near-ground branch density of four thorny species: Vachellia nilotica, Senegalia laeta, Senegalia mellifera, and Prosopis juliflora. Physical measurements and photographic data indicated that after one growing season, $V$. nilotica was a superior thorny hedge species with significantly higher values in all metrics, while $P$. juliflora performed poorly in all metrics. Pruning treatments did not increase branch density compared to control treatments, suggesting that selection of hedge species may be more important than the pruning regimen for establishing thorny livefences.
\end{abstract}




\section{INTRODUCTION}

From 2014 to 2016, I served as a Peace Corps Volunteer in Senegal, West Africa as part of the Peace Corps Master's International program at Michigan Technological University. I was assigned through the Ministry of Agriculture to serve as a Sustainable Agriculture Extension Agent in Dialakoto, a rural village in the Tambacounda Region of Senegal. My primary responsibility was to increase food security and agricultural sustainability through the transfer of appropriate skills and technologies to local farmers. One important component of increasing food security is preventing losses of field, garden, and orchard crops to abiotic and biotic stressors.

During my first week in Dialakoto, a community counterpart, Ousmane, invited me to join his family in harvesting their bean and hibiscus field. I got up early one morning and we walked several kilometers to their field only to find nothing but stubble. A migratory livestock herd had passed through the area and browsed their entire field of crops. Additionally, throughout my service, I was repeatedly frustrated when after successfully employing new techniques with gardeners, the garden would be destroyed by goats or sheep before the benefits of the new technique could be observed by the gardener. My work partners rarely had the time or motivation to restart their garden and thus I would have to wait a full year to regain the opportunity to work with them again.

These experiences inspired me to extend the technology of thorny hedges to local farmers as a means to protect their agricultural spaces. In rural West Africa, most villagers are subsistence farmers: what they grow is the majority of what they eat. Any harvest losses means less food for their families or more money necessary to supplement their harvests with purchased food. 
Agricultural losses are due to many stressors. While some stressors, such as drought, inconsistent rain, or pest outbreaks, are beyond a farmers control, other sources of loss, such as livestock herbivory and theft, are preventable. In Senegal, as in much of West Africa, herbivory by domesticated and wild animals can be a significant source of crop loss to farmers, gardeners, and orchard owners (Landais \& Guerin 1991, Lindsey et al. 2012, Louppe \& Yossi 1999). The solution to this problem seems simple: exclude herbivores by fencing. However, lack of financial resources, limited access to quality materials, and voracious termites make this seemingly simple task quite challenging. Thus, planting thorny hedges is extended as an affordable and sustainable solution, but little research has been published or shared publicly to guide best practices for cultivating a successful thorny hedge. Therefore, this study aims to better inform thorny hedge establishment practices by investigating how early pruning influences the near-ground branch density of four thorny hedge species, and whether these hedge species differ in their branching patterns with and without pruning. 


\section{BACKGROUND}

\section{Agriculture in Senegal}

In Senegal, $78 \%$ of the labor force participates in agriculture and $46.8 \%$ of the land base is put to agricultural uses (CIA 2016). There is a $46.7 \%$ poverty rate and within the Tambacounda region, where the study took place, subsistence agriculture dominates. The main crops of the region are millet, sorghum, maize, peanuts, and rice to a lesser extent (CIA 2016, ANSD 2015). Irrigation is not a viable option for the vast majority of rural farmers, so most farmers are only able to produce food during the single rainy season. Additionally, since the 1970's, precipitation patterns have been unreliable, decreasing the margin of error for failure. So, any losses to crop yields can greatly affect livelihoods.

\section{Migratory Pastoralism}

One potential source of loss is herbivory by herds of livestock which migrate across the Senegalese landscape each year. Most of these herds are owned or managed by people of the Fulani ethnicities. The Fulani peoples are traditional herders from West Africa whose various groups now span the Sahelian zone from Senegal to Ethiopia. While most Senegalese practice animal husbandry, the Fulani of northern Senegal traditionally practice migratory livestock herding. However, during the mid-twentieth century many Fulani in Northern Senegal began abandoning the traditional migratory lifestyle and forming permanent agro-pastoral settlements around recently dug deep-bore wells. Then, the drought of the 1970's profoundly changed the livelihood strategies of these communities again ( $\mathrm{Ba}$ 1986). The inability to grow substantial crops and the need to travel long distances in search of good 
pasture redirected many Fulani back towards migratory pastoralism (Adriansen 2008, Basset 1988).

The rise of specialty markets, such as for Tabaski sheep, has also meant that the returns-on-labor of migrating in search of better pastures are worthwhile (Adriansen 2005). Tabaski is the Wolof word for the holiday Eid alAdha, which implores all Muslim men to buy and sacrifice a ram. It has become commercialized in Senegal, and as the economy has grown, urban populations are willing to pay handsomely for prize rams. There has also been a larger regional expansion of Fulani herders southward, as observed by Stenning (1959) and others.

This range expansion coupled with increasing population pressure on agricultural lands, and increasing individualization of land tenure, has resulted in more frequent interactions between the pastoral and farming systems, and therefore more opportunity for conflict (McCown et al. 1979). The dynamics between Fulani herders and sedentary farmers, some of whom are Fulani themselves, is quite complex. In reality, many Fulani people are sedentary and most modern migrating herders are boys and young men who are hired or assigned the task (Adriansen 2008).

Typically, migratory Fulani herders in Senegal travel a roughly northsouth cycle following the flush of vegetation from the rainy season. There is a striking rainfall gradient in Senegal, with the southern regions receiving as much as four times the annual rainfall of the northern pasture lands (Tappan et al. 2004). In the fall, once the vegetation in the northern pastures has been grazed, herders move southward into lands which receive higher annual rainfall and support more vegetative biomass. The herds graze the richer southern lands throughout the dry season, sometimes continuing southward in search of better pastures (Adriansen 2008). Once they meet the rains, they 
head north again following the flush and spend the rainy season in the traditional pasturelands of northern Senegal (Adriansen 2008). This pattern has been observed historically (Stenning 1959), but declining ecological conditions have resulted in a higher potential for conflict. Miehe et al. (2010) conducted a unique long-term study which found that despite short-term fluctuations often reported in the literature, forage quality in Senegal's northern pastures has been decreasing. Consistent grazing has degraded these pastures in the later part of the twentieth century. This decreasing forage quality coupled with changing climate patterns can change the timing of migrations, resulting in herds arriving earlier in the fall, often before crops are fully ripened or harvested. Careless herders can easily cause the destruction of a family's farming efforts just before the crops are mature, destroying a season's worth of work and a year's worth of food.

While some Fulani herders simply travel through the countryside, others have agreements with local farmers in which their livestock can graze on crop residues and sleep on the farmer's fields at night, depositing manure in return (Blench 1984). In pre-colonial times, these mutually beneficial relationships were common between these two systems, and while they are still practiced today, the context has changed with climate, land cover, and politics (Davidhaiser \& Luna 2008). As Hussein et al. (1999) note, conflict inevitably arises as a result of the increasing limitation of the shared resource of land. Conflict resulting from losses to crops and fruit trees by herbivory has been widely documented across Africa, and while Senegalese pastoralists and farmers have been interacting for generations, conflict still exists (Basset 1988, Blench 1984, Breusers et al. 1998, Magistro 1993, Landais \& Guerin 1991, Lindsey et al. 2012, Louppe \& Yossi 1999). 


\section{Local Herds}

Hussein et al. (1999) points out that in modern times it may be erroneous to differentiate between herders and farmers, as most farmers practice some degree of animal husbandry. Traditionally, in West Africa, farming and pastoralism were distinctly separate systems, but there has been a blurring of lines over the past century; now most people participate in both systems to some degree (McCown et al. 1979, Toulmin 1983). The study site of Dialakoto, like most of Southern Senegal, practices agrosilvopastoral management, which as described by Ayuk (1997) involves trees, crops, and livestock occupying the same land. However, it is not always a highly intentional integration. Animal husbandry has been adopted by all ethnicities in Senegal and local 'household herds' of one to twenty animals are omnipresent. Often wealthy landowners even hire Fulani herders to guard their larger herds, as mentioned in Basset (1988) and McCown et al. (1979), and as practiced by the owner of this study's research land (Drame per. comm.).

During the farming season these local herds are kept in check by village decree. They are corralled at night and watched or leashed during the day to ensure the safety of the community's crops and to avoid conflict. However, the animals are not under watch during the dry season and wander freely during the time of year that gardens and tree nurseries are propagated. These local animals often destroy gardens, tree nurseries, and drying grains as documented by Ayuk (1997) in Burkina Faso. In fact, Ayuk (1997) found that dry season damage to high value products is an important factor in the adoption of live-fencing technologies, and this is consistent with my own experiences extending thorny hedge technology in Dialakoto. 
While herbivores likely pose a greater threat to crops and gardens, theft can be a serious threat to fruit orchards. In rural areas, sweet foods are a rarity and the chance to feast on stolen fruit, or sell it, is hard to pass up. In fact, the owner of the study's research site lost hundreds of watermelons to theft (Drame per. Comm).
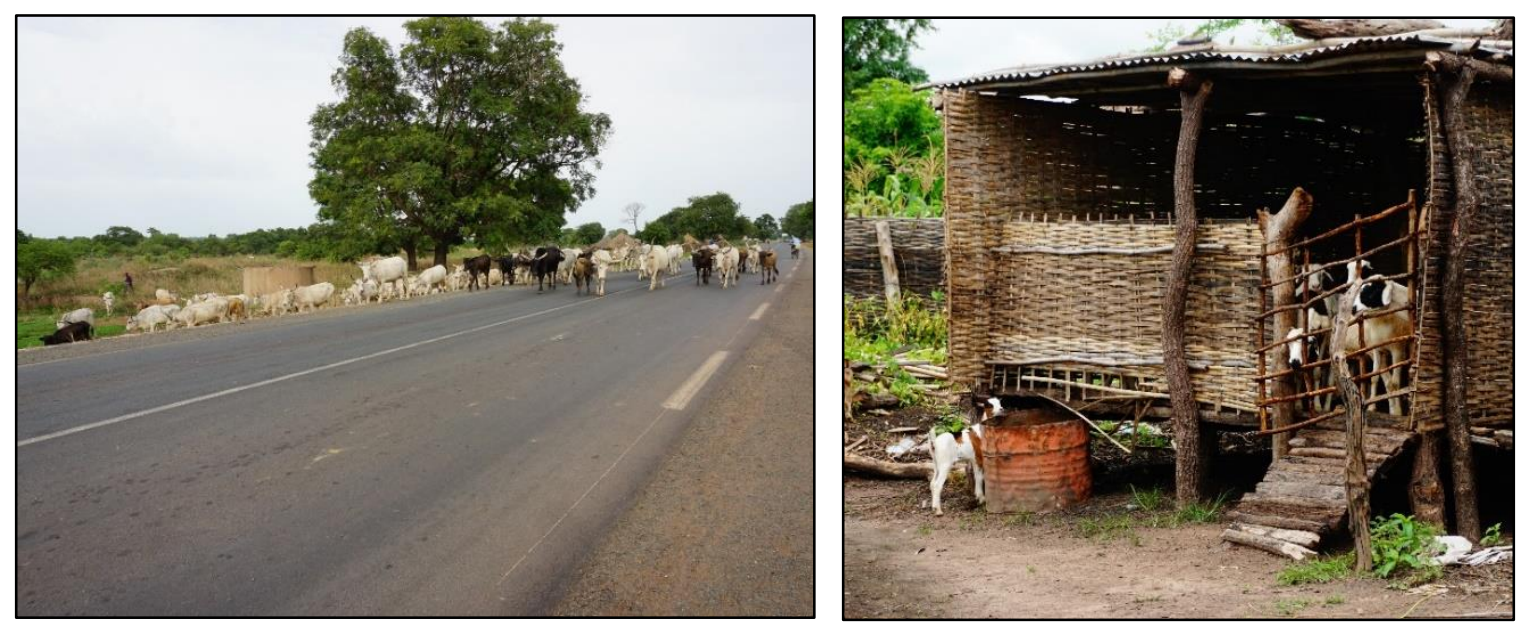

Figure 1. A large migrating herd (left) and a small local herd (right). Personal photography by Gwen Jacobson

\section{Fencing Options}

For farmers, taking legal action against thieves or owners of livestock that have destroyed their agricultural products can be a time-consuming process; and often it is impossible to identify the culprit. Farmers cannot constantly monitor all their lands and there is very little accountability for damages done. As a result, the onus is on the farmers to protect the fruits of their labor. The obvious and most effective solution is fencing. The most common fencing materials in Senegal are metal chain-link or a variety of dead vegetative materials. The chain-link found in Senegal is of low quality, deteriorates quickly, and more importantly is cost-prohibitive. The cost for materials alone to fence one hectare of land was 1892.89 USD in 2014 (Massaly 
et al. 2014) while the per capita income in Senegal that year was 2400.00 USD (CIA 2017, Treasury 2015). Within Senegal and greater West Africa, individual farm size varies but is generally between 2-10 hectares (Kelly et al. 1996, Maertens 2009, Thuo et al. 2011), making chain-link an unrealistic option for most farmers.

The use of dead woody materials such as poles, dead thorny branches, woven bamboo, or woven millet stalks is common in West Africa (Ayuk 1997, Howes 1946) but not a particularly appealing alternative. Fencing a hectare with woven bamboo fencing costs 371.26 USD in materials (author's personal experience) while dead wood or woven millet fencing generally costs only the price of multiple days of labor. Despite the lower cost, these dead cellulosebased fences are labor intensive, unsustainable, and highly susceptible to termite damage (Ogada et al. 2003, Rocheleau et al. 1988). They have a life expectancy of only 2-4 years due to the voracious termites that are ubiquitous in subtropical Africa. This short lifespan was not an issue historically when deadwood fences made sense in rotating fallow agricultural systems, but currently fields are continuously cultivated and long-lasting fencing is preferable (McCown et al. 1979).

Live-fencing has been proposed as a sustainable and low-cost alternative to metal or deadwood fencing, and has been utilized across the developing world both historically and recently (Ayuk 1997, Butterfield and Niamy 1996, Henderson 1983, Howes 1946, Lindsey et al. 2012, Louppe \& Yossi 1999, Madany 1991, Mahat 1993, Martin 1991, Ouangraoua1988, Rocheleau et al. 1988, Sanogo et al. 1999, Seignobos 1980, Sharma \& Devi 2013, Tengnäs 1994). The general term 'live-fence' can refer to living fence posts, spaced boundary markers, unpalatable hedges, or thorny hedges. Thorny hedges are the focus of this study and their use has been documented as early as the 1500's on the 
Iberian Peninsula (Ramón-Laca 2015). Ayuk (1997) describes a hedge a closely spaces $(25-50 \mathrm{~cm}$ apart) shrubs planted in a row to form a continuous barrier around an area.

\section{Thorny Hedges}

In arid areas, where accumulating biomass is a constant struggle, many woody species use spines and other structural characteristics, such as dense branching and a wide canopy, to defend against herbivory. These structures form a cage-like crown (Bond et al. 2001), especially when heavily browsed, which protects the internal parts and main biomass of the plant. (Archibald \& Bond 2003, Cooper \& Owen-Smith 1986, Gowda 1996, Milton 1991, VeseyFitzGerald 1973). These evolutionary traits can be utilized by humans to form a protective barrier against herbivory of agricultural products. Across Africa, cuttings of thorny species have been coarsely woven to form fencing traditionally, but such dead material is more susceptible to termites and not as flexible or resistant to breaking as living branches (Ogada et al. 2003, Rocheleau et al. 1988). By planting densely-branching thorny species in close proximity along a perimeter, a thorny hedge can be formed which is selfregenerating and resistant to damage. They can take $3-5$ years to form an effective barrier and growth can vary greatly based on local conditions. Soil characteristics, exposure to wildfire, pruning frequency, and herbivory can all greatly affect time to establishment. However, Ayuk (1994) studied the economics of hedges within West Africa and found that returns-on-labor of the initiation and upkeep of a living hedge is greater than that of a dead-wood fence. While yearly upkeep is required, it amounts to fewer person-hours of labor than those required by the regular collection of material and rebuilding of dead-wood fences. 
Thorny hedges are a multi-benefit technology. Not only do they protect a farmer's investment in agriculture, but live fencing and hedgerows also act to reduce water and wind erosion to soils, capture nutrient rich dust, and potentially provide fodder from prunings, firewood, or fruits from certain species (Forman \& Baudrey1984, Louppe \& Yossi 1999, Rocheleau et al. 1988, Stoorvogel et al. 1997, Young 1989). Plus, thorny species formerly classified as Acacias are known nitrogen fixers and their cuttings and litter can be used for mulching purposes as well (Schulze et al. 1991, Young 1989).

Various species of this former Acacia genus (including three in this study) are commonly used for fencing due to their thorniness, bushy growth habit, drought tolerance, and speed of growth (Levasseur et al. 2004, Louppe \& Yossi 1999, Madany 1991, Martin 1991, Sanogo et al. 1999, Sharma \& Devi 2013, Wickens 1995). In Kenya, living and uprooted Acacia bushes were found to be effective at deterring wildlife (Ogada et al. 2003) and, Fornara \& Du Toit (2007) and Dangerfield \& Modukanele (1996) both found Acacia species to increase branching in response to clipping.

\section{Research Direction}

During my time in Senegal with the Peace Corps, I was inspired to investigate best practices for thorny hedges because I found so few researchbased guidelines. Peace Corps and other Development Organizations give broad and inconsistent recommendations on best practices regarding thorny hedge establishment, specifically timing and height of pruning. Most recommendations also appear to be based on anecdotal evidence, not research. As Yossi et al. (2006) states, there is little research available to inform technical extension activities. Many agroforestry manuals and guides have limited or no specifications on the establishment and upkeep of thorny hedges 
beyond propagation methods, and those that do, differ greatly in their recommendations (Matarasso et al. 2003, Pineau \& Tsatsu 2010). Ayuk (1997) comments that much research has been undertaken regarding bio-physical aspects of living-hedges, such as species-specific propagation techniques, but that methodological issues are still in need of testing. In my literature search, I found evidence of and reference to studies on thorny hedges, but most results were not readily available in libraries or literature databases. Thus, this thesis aims to add to the body of knowledge regarding thorny-hedges and best practices for their establishment.

Near-ground limb density is a key determinant of the effectiveness of thorny hedges at excluding herbivores, particularly goats and sheep; Figure 2. Steavenson (1946) found that livestock utilize near-ground openings to infiltrate hedges and I personally observed low near-ground limb density to be a common failing of ineffective thorny hedges in Senegal. Hien \& Zigani (1987) comments on the critical role of low branching in the effectiveness of thorny hedges and Cole (1980) notes that if a thorny hedge is not pruned early it will
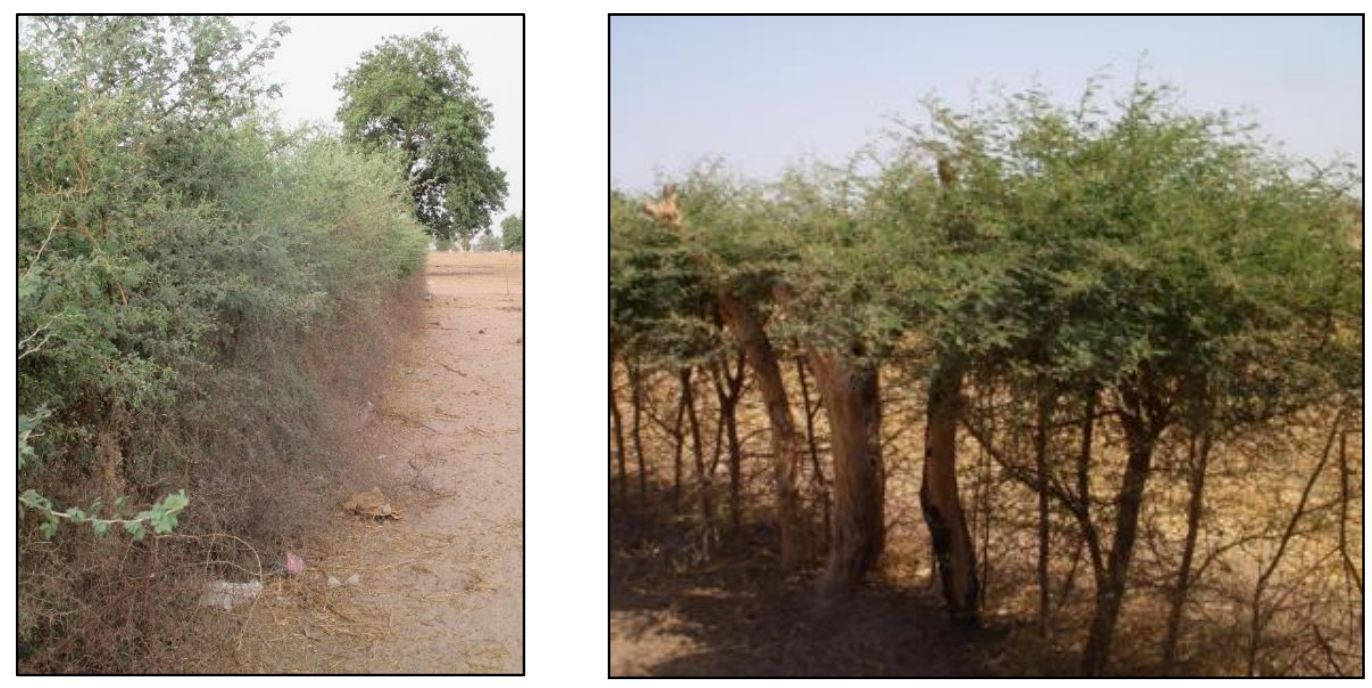

Figure 2. Effective and ineffective thorny hedges. The image on the left has high near-ground limb density while that on the right has not been properly established and has large near-ground gaps. Images taken from Kelley et al. (2016). 
have a thick upper canopy and be open below. Trees for the Future (2008) also states that establishment of early branching is critical because a fence is only effective if there are low branches. So, while regular pruning of a hedge is known to create a dense heavily branched form (Cole 1980, RHS 2015, Yoosi 2006) there is no clear guidance on how to best develop high near-ground limb density.

Early pruning, pruning a plant in the nursery or at out-planting, is a technique commonly recommended for thorny hedge nurseries by agroforestry extension agents in Senegal. It aims to set a thorny hedge up for success by establishing low lateral branching early. It is widely known that pruning woody plants typically results in branching. The excision of shoot tips, a.k.a. pruning, has been shown to release apical control resulting in branch shoot development (Bannister \& Watt 1995, Cline 1997). Apical control is the repression of lateral bud growth by the shoot apex (Cline 1994). While lateral buds always form on plants, their development is commonly inhibited by controls from the main apical bud (Steeves and Sussex 1989, Suzanne et al. 2005). At the most basic level, removing the apical bud releases this control and induces growth of lateral shoots. While older woody plants do not follow this simplified model of apical dominance, this model is followed within the first year of a woody plant's life (Cline 1997). Therefore, removing the apical bud of a thorny hedge plant within its first year should result in lateral branching. However, this practice seems to be based more on anecdotal evidence than research results.

To access this practice, the effects of several early pruning techniques on the near-ground limb density of four highly regarded thorny hedge species was investigated. This study aimed to improve the implementation of thorny hedge technology by investigating three questions. First, does a plants position 
in the nursery impact its growth habit? Protected spaces in which to house tree nurseries and gardens are at a premium in West Africa and farmers prefer to use those spaces as efficiently as possible. Therefore, a typical tree nursery will contain hundreds of pots in densely-packed rows. There is the potential that plants grown in the center of such nurseries will allocate more resources towards vertical growth than horizontal branching, reducing their effectiveness for thorny hedges and potentially skewing the data in relation to the next two questions. Second, which of four highly regarded thorny hedge species: Senegalia laeta, Senegalia mellifera, Vachellia nilotica, and Prosopis juliflora exemplify the desired hedge traits? Third, do any of three commonly recommended early pruning treatments: removing the terminal bud once the plant reaches $50 \mathrm{~cm}$ height in the nursery, trimming the main stem to $50 \mathrm{~cm}$ height at out-planting, removing the terminal bud at out-planting, and a control sample improve a plant's ability to meet the desired criteria? 


\section{METHODS}

\section{Site Description}

The experiment was conducted from May to October 2016 in Dialakoto, Senegal $\left(13.316285^{\circ} \mathrm{N}, 13.284699^{\circ} \mathrm{W}\right)$. Dialakoto is a village of approximately 3,500 people in the Tambacounda region of southeastern Senegal. The majority of the population belong to the Mande ethnicities while the remainder of the population belong mostly to the Fulani ethnic groups. As in most of Senegal, the majority of Dailakoto's residents are Muslim.

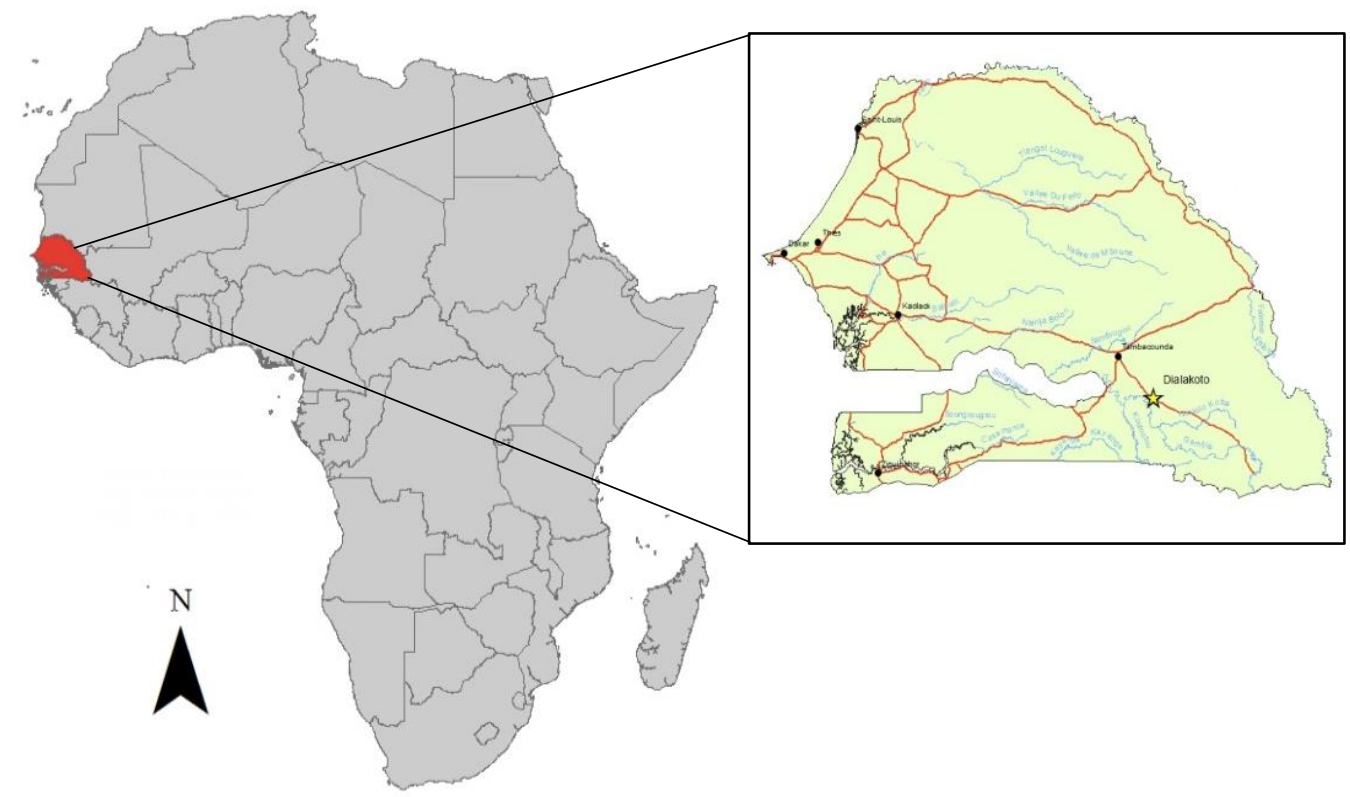

Figure 3. Location of Senegal within Africa, and the study site, Dialakoto, within Senegal.

Dialakoto is located on the N7 highway running between the regional capitols of Tambacounda and Kedougou. The area is bordered to the north by Diambour National Forest and to the south by Niokolo-Koba National Park. This Sudano-Sahelian transition zone has three strongly defined seasons; a 
cool dry season from November to February with temperatures in the low thirties Celsius, a hot dry season from March to June with temperatures in the low-forties Celsius and strong harmattan winds from the Sahara Desert, and a wet season from July to October with temperatures in the mid-thirties Celsius. During the single growing season, Dialakoto receives an average annual rainfall of approximately $800-1000 \mathrm{~m}$. Local soils are broadly classified as shallow loamy and gravelly over laterite on plateaus and as deep sandy to loamy leached tropical ferruginous in valleys and on terraces where agriculture takes place (Tappan et al. 2004). The dominant land cover type is woodland savanna and the dominant woody vegetation includes: Combretacea spp., Manguifera indica, Terminalia macroptera, Cordyla pinnata, Pterocarpus erinaceus, and Detarium microcarpum (Tappan et al. 2004).

The majority of Dialakoto's residents are subsistence farmers and most non-conservation lands are agricultural parklands with commonly cultivated crops including millet, maize, rice, sorghum, cowpea, peanut, and cotton (ANSD 2015). Common livestock include donkeys (Equus africanus asinus), cows (Bos taurus) for animal traction, and sheep (Ovis aries) or goats (Capra aegagrus hircus) for meat production and as an investment strategy.

\section{Variables Investigated}

The thorny species investigated were Senegalia laeta, Senegalia mellifera, Vachellia nilotica, and Prosopis juliflora; all are considered excellent species for thorny hedges (Sidibe et al. 2012, Wickens 1995). They all meet the criteria developed by Ayuk for successful hedges (1997), including resistance to drought, rapid growth, and protective efficiency.

V. nilotica (formerly Acacia nilotica) is a tree native to Senegal with pairs of straight long thorns at the base of its leaves. S. mellifera (formerly 
Acacia mellifera) is a thorny shrub or small tree native to eastern Africa with hooked pairs of thorns at the base of its leaves. S. laeta (formerly Acacia laeta) is a thorny tree or shrub native to Senegal with 2-3 curved thorns at the base of its leaves. $P$. juliflora is a short tree native to the deserts of the Americas with straight solitary or paired thorns at the base of its leaves. S. laeta, $S$. mellifera, and $V$. nilotica are typically found in Sahelian or Sudanian habitats and are very drought resistant. $P$. juliflora is naturalized throughout dry West Africa and also drought resistant. (Arbonnier 2004, Sidibe et al. 2012)

Three experimental pruning treatments were applied, all early pruning practices recommended by the Peace Corps and the Senegalese Forest and Water Service to induce early branching (Sidibe et al. 2012 , Djitte 2015 per. comm., Sane 2016 per. comm.): 1. removing the terminal bud once the plant reaches $50 \mathrm{~cm}$ height in the nursery, 2 . trimming the main stem to $50 \mathrm{~cm}$ height at out-planting, and 3. removing the terminal bud at out-planting. A control sample was maintained that entailed no pruning treatment; Figure 4. Hien \& Zigani (1987) also suggested that the first pruning be at $50 \mathrm{~cm}$ height.
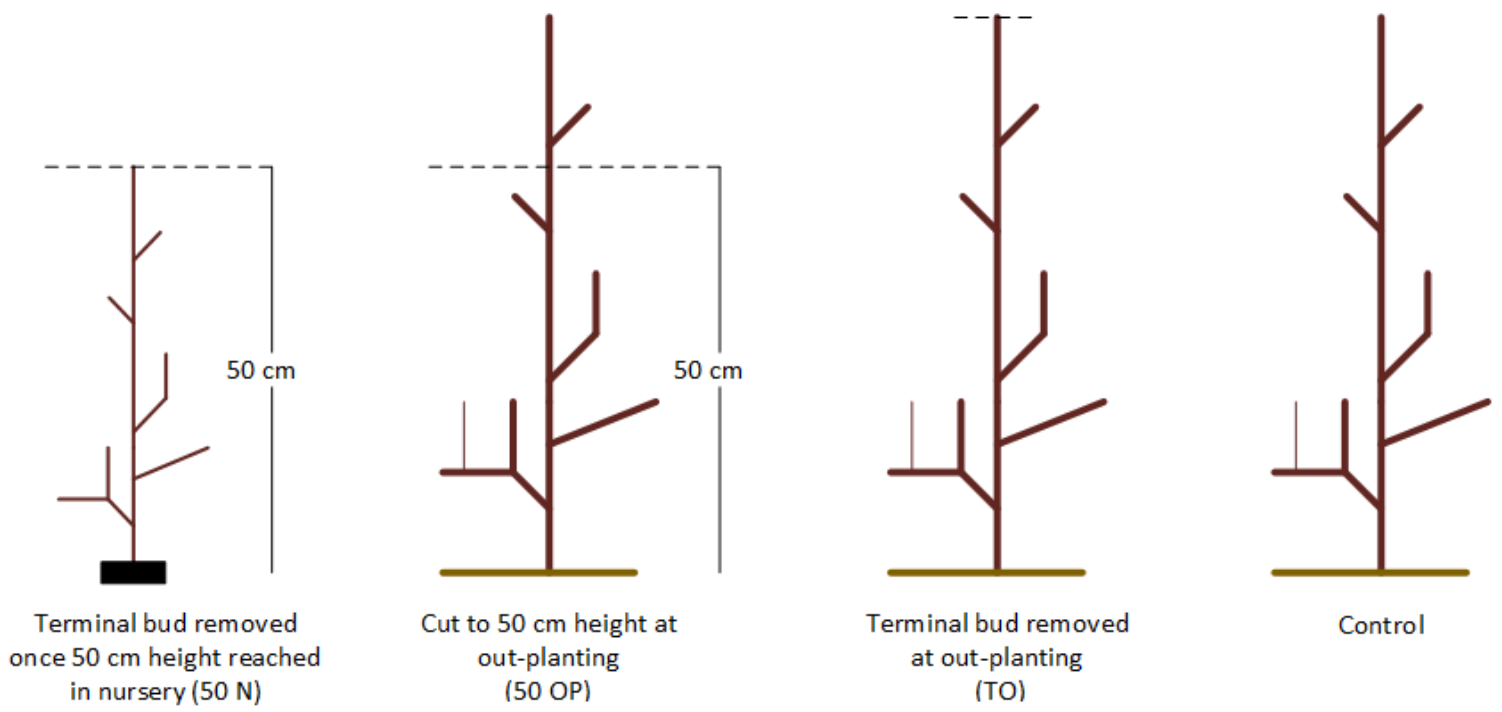
ut-plantin

Figure 4. The experimental treatments applied. Height refers to the length of the main stem, not the distance above ground level. 


\section{Research Nursery}

The research nursery was located in a common garden in the village of Dialakoto at $13.31775491^{\circ} \mathrm{N},-13.28711344^{\circ} \mathrm{W}$. The nursery medium consisted of a 2:1 ratio, by volume, of sand to composted sheep and goat manure. For each six liters of sand and three liters of manure, one liter of water was added to the substrate for ease of potting. Soils were potted in common one-liter black poly-pots. The nursery was twelve pots wide by forty-two pots long for a total of 400 experimental pots arranged in a randomized layout with a 1-pot edge buffer; Figure 5. Each nursery row consisted of two sets of pots, with each set

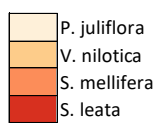

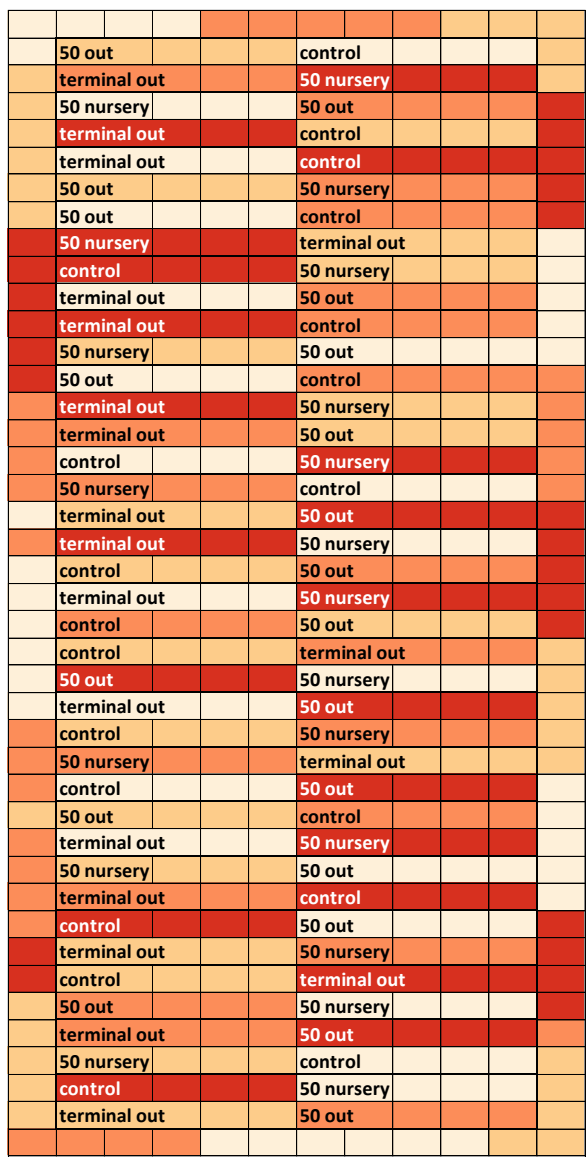

Figure 5. Experimental nursery layout. The treatments are: removing the terminal bud once the plant reaches $50 \mathrm{~cm}$ height in the nursery; trimming the main stem to $50 \mathrm{~cm}$ height at out-planting; removing the terminal bud at out-planting, plus a control sample (no pruning). 
consisting of five seedlings of the same species receiving the same treatment. Every two rows (four sets) contained representation of all four species and all four treatments; Figure 5. This randomized layout was used to eliminate the potential for early growth in the nursery to bias results after out-planting if location in nursery influenced speed, direction, or pattern of seedling growth. This design resulted in one hundred individuals per species, one hundred individuals per treatment, and twenty-five individuals per species-treatment combination. A position number was assigned to each pot for the analysis of location affects within the nursery. This number was based on the pots relationship to the nearest nursery edge with position 1 being edge pots and position 6 being those in the center of the nursery; Figure 6 .

\begin{tabular}{|l|l|l|l|l|l|l|l|l|l|l|l|}
\hline 1 & 1 & 1 & 1 & 1 & 1 & 1 & 1 & 1 & 1 & 1 & 1 \\
\hline 1 & 2 & 2 & 2 & 2 & 2 & 2 & 2 & 2 & 2 & 2 & 1 \\
\hline 1 & 2 & 3 & 3 & 3 & 3 & 3 & 3 & 3 & 3 & 2 & 1 \\
\hline 1 & 2 & 3 & 4 & 4 & 4 & 4 & 4 & 4 & 3 & 2 & 1 \\
\hline 1 & 2 & 3 & 4 & 5 & 5 & 5 & 5 & 4 & 3 & 2 & 1 \\
\hline 1 & 2 & 3 & 4 & 5 & 6 & 6 & 5 & 4 & 3 & 2 & 1 \\
\hline 1 & 2 & 3 & 4 & 5 & 6 & 6 & 5 & 4 & 3 & 2 & 1 \\
\hline 1 & 2 & 3 & 4 & 5 & 6 & 6 & 5 & 4 & 3 & 2 & 1 \\
\hline 1 & 2 & 3 & 4 & 5 & 6 & 6 & 5 & 4 & 3 & 2 & 1 \\
\hline 1 & 2 & 3 & 4 & 5 & 6 & 6 & 5 & 4 & 3 & 2 & 1 \\
\hline. &. &. &. &. &. &. &. &. &. &. &. \\
\hline. &. &. &. &. &. &. &. &. &. &. &. \\
\hline. &. &. &. &. &. &. &. &. &. &. &. \\
\hline
\end{tabular}

Figure 6 . The assignment of position number within the nursery.

All seeds were pre-treated to increase germination rate (Sidibe et al. 2012). S. mellifera, S. laeta, and $V$. nilotica seeds were manually scarified followed by a twelve-hour cold-water soak. P. juliflora seeds were treated with a twelve-hour hot water soak. Because $V$. nilotica typically requires more time in the nursery before reaching out-planting size, it was seeded earlier than the other species (Sidibe et al. 2012); Figure 7. V. nilotoca was seeded 10 May and 


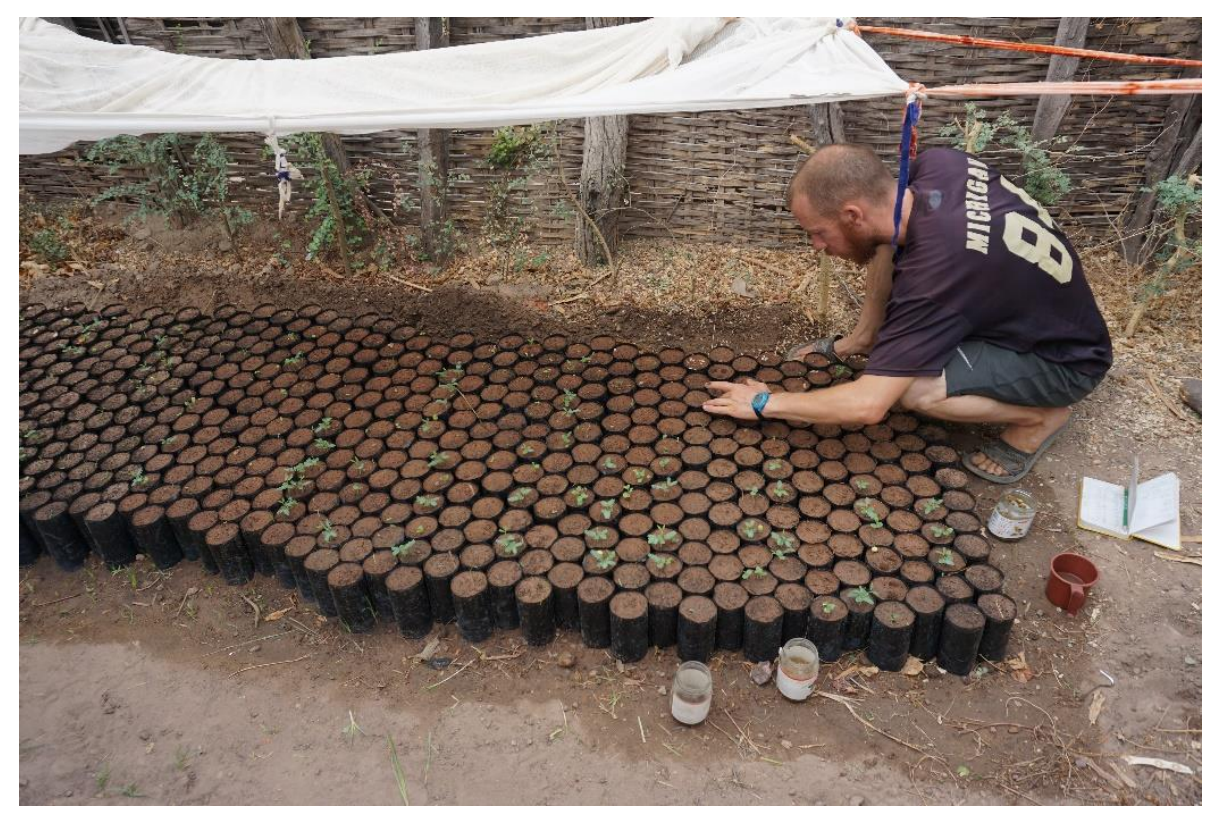

Figure 7. The author seeding the experimental nursery, with $V$. nilotica germinating. Personal photography by Gwen Jacobson.

pots which did not germinate were reseeded 20 May. S. laeta, S. mellifera, and $P$. juliflora were first seeded 20 May and empty posts were reseeded on 26 May. Three seeds were seeded in each pot to a depth of approximately twice the seed's width. After initial germination, pots were thinned to two seedlings per pot. On 7 June all pots were thinned to 1 seedling. The nursery was watered daily unless a rain event occurred. A common woven bug-net was installed over the nursery for initial protection of the seedlings from herbivory and solar radiation; Figure 6 . The netting was removed 30 June to harden off the seedlings and provide vertical growing space. At that time the research trees were marked with a loop of colored plastic coated wire around the lowest branch to indicate experimental treatment.

\section{Planting Site}

The experimental planting site was a two-hectare market garden owned by a local entrepreneur. The parcel was fenced with chain-link in 2015 . 
Planting inside this fence excludes the impacts of livestock herbivory on the research plants. The research fence spanned from $13.3133343^{\circ} \mathrm{N}$, $13.27526352^{\circ} \mathrm{W}$ to $13.31350478^{\circ} \mathrm{N},-13.27665567^{\circ} \mathrm{W}$ with a gap for an entrance gate. The research fencing was planted along the northern border of the garden's fence line where the slope was minimal and soil texture consistent. Soil texture was found to be a sandy loam using the ribbon test (Adepetu et al. 1996), which was supported by ISRIC soils data (Batjes 2008). On 16 and 17 July, S. laeta, $S$. mellifera, and $V$. nilotica trees were transported to the planting site and planted 17-20 July. $P$. julilflora individuals had not yet reached out-planting size and remained in the nursery until planting on 9 August. Not all $P$. juliflora seedlings reached an appropriate size for use in experimental data, but all seedlings were planted regardless in order to preserve the experimental design. Additionally, three edge seedlings were planted at each end and at the break in the hedge for the gate.

A two-meter corridor was weeded twice (25 August and 17 September) to bare soil in preparation for planting and to reduce competition from weeds. Seedlings were planted in holes that were equivalent in size to the pots, approximately one liter. Based on common spacing recommendations, seedlings were spaced at $35 \mathrm{~cm}$ intervals and planted $50 \mathrm{~cm}$ inside the chainlink fence, (Howes 1946, Kelley et al. 2016, Rocheleau et al. 1988, Tengnäs 1994, Tree for the Future 2008). Watermelons were grown in the space adjacent to the experimental fence. The layout of the research fence can be found in Appendix A. Seedlings were watered-in heavily for three days and were rain-fed thereafter. 


\section{Treatment Application}

On 30 June, when the average height of the S. laeta, S. mellifera,and $V$. nilotica seedlings in the nursery was $50 \mathrm{~cm}$, the terminal buds were removed from twenty-five seedlings of each species. Because P. juliflora individuals had not reached an appropriate size by 30 June, their terminal buds were not removed until they reached $50 \mathrm{~cm}$ height on 31 July. The other two experimental treatments, removing the terminal bud at out-planting and pruning the main stem to $50 \mathrm{~cm}$ height at out-planting, were applied immediately after planting.

\section{Data Collection and Analysis}

While plants were still in the nursery, initial data was collected from 1415 July during the preparation of the plants for transportation to the planting site. Data was gathered on plant height, branching heights along main stem, and position in relation to the nearest nursery edge (from 1 to 6). A pot at position 1 is an edge pot while those at position 6 are in the middle, with five pots between them and the edge of the nursery; Figure 6. Plants near a corner were assigned the lowest position number applicable. Final physical data collection took place 7-9 October after the end of the rainy season. Data collected included main stem length and heights of branching along main stem. Physical measurements were gathered by hand using a standard measuring tape.

Density of stems below $35 \mathrm{~cm}$ was reported in this study. Stems refers to the main stem, forks off the main stem, and primary branches. The area below $35 \mathrm{~cm}$ was selected for study based on the average shoulder height $\left(65^{-75 \mathrm{~cm})}\right.$ of female Sahelian goats which are the dominant goat breed in Senegal (Dept. of 
Animal Sciences 1999). Since Sahelian goats have been observed to crawl under obstacles as low as half their height, the density of branches below half a smaller goat's height was determined to be appropriate for investigation.

Photo data of each individual plant was gathered 12-14 October to measure the spread of each seedling (better spread makes a better fence). Photos were taken approximately two meters away with the camera at an approximate right-angle to the hedge-line. Camera height was approximately $35 \mathrm{~cm}$ but varied somewhat due to micro-topography. Initial processing of the photos was completed using the Gimp 2.8 application (Kimball \& Mattis 2015). An image layer indicating the presence or absence of a branch was overlaid by a grid with cell size equivalent to one centimeter in the photograph. The grid was thirty-five cells $(35 \mathrm{~cm})$ wide, which is equal to the horizontal spacing of each plant, and thirty-five cells $(35 \mathrm{~cm})$ tall, which represents the height below which animals are likely to penetrate gaps. The root collar of the plant in question was centered on the bottom margin of the grid. See Figure 7 for an example and Appendix $\mathrm{C}$ for detailed steps used to process the photo data. Any grid cell which included woody stem, thorns, or was $50 \%$ occupied by other
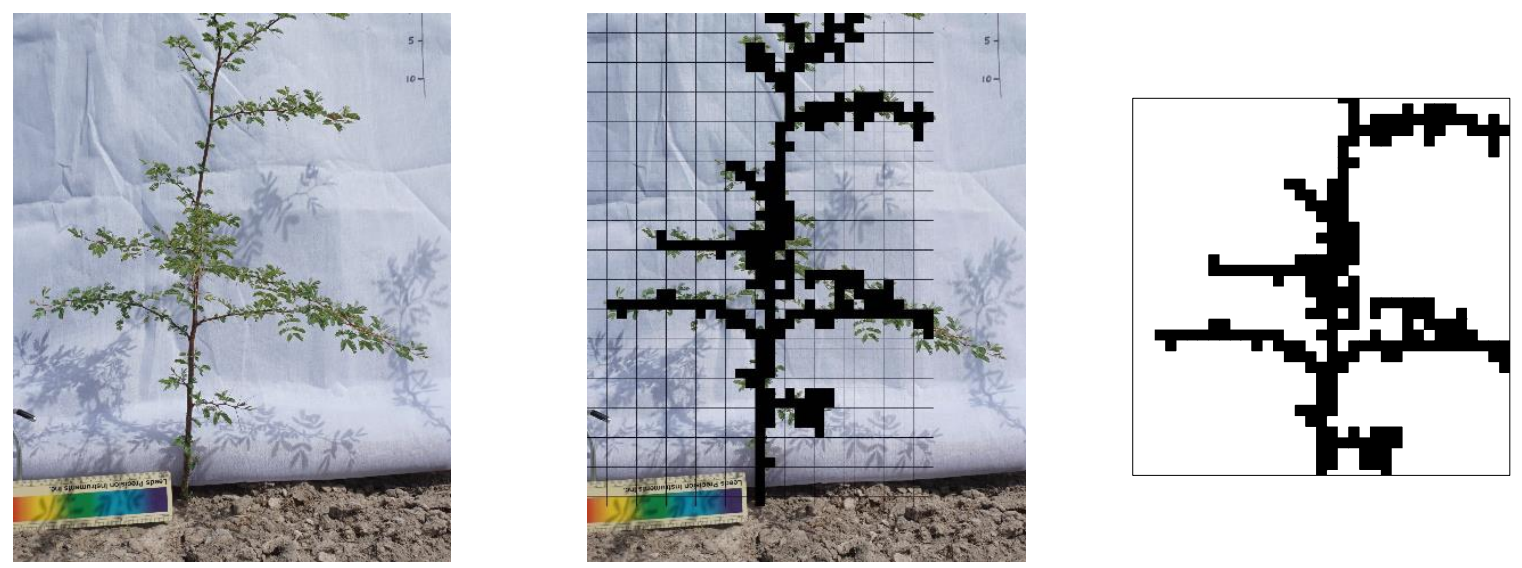

Figure 8 . The stages of processing the photographic data. First the image was overlaid with a grid with cell size equivalent to $1 \mathrm{x} 1 \mathrm{~cm}$. Any cell which included woody stem, thorns, or was $50 \%$ occupied by other plant material of the individual of interest, was counted as occupied and filled. The $35 \times 35 \mathrm{~cm}$ grid was then isolated for analysis. 
plant material of the individual of interest, was counted as occupied by the seedling and marked.

After the individual image had been gridded, the grid layer was isolated, copied, and converted to a 1-bit black and white Tiff image; Figure 7. Tiff files were transformed to GeoTiffs using an iteration modeled in ArcView GIS (ESRI 2015, Hyslop pers. comm.). Once georeferenced, the GeoTiffs were analyzed using the FRAGSTATS application (McGarigal 2015). The Fragstats parameters PLAND and ED were calculated and the results analyzed. PLAND calculates the percentage of the landscape or input image that is occupied by each class of pixels; in this case, a pixel was classified as either "plant" or "no plant", reflecting the percentage of a plant's assigned space it was occupying. ED calculates the edge density of the space occupied by the plant. A higher edge density indicates a higher degree of complexity to the plants form, indicating a higher degree of branching, resulting in a greater ability to occupy its assigned space.

All data was log-transformed to increase normality of the distribution and was analyzed using ANOVA. As mentioned above, some $P$. juliflora seedlings were not developed enough to receive experimental treatments and were therefore not included in the data. In combination with mortalities during the growing season, this resulted in the sample sizes deviating from the original experimental design; Tables 1 and 2. Therefore, significance in the species and position comparisons was determined using the Tukey HSD post-hoc test. Significance in the treatment comparison was determined using Dunnett's post-hoc test against a control. 
Table 1. Sample sizes for the nursery data analysis.

\begin{tabular}{c|cccc|c}
$\begin{array}{c}\text { Nursery } \\
\text { Position }\end{array}$ & V. nilotica & S. mellifera & S. laeta & P. juliflora & Total \\
\cline { 2 - 6 } $\mathbf{1}$ & 27 & 26 & 21 & 26 & 100 \\
$\mathbf{2}$ & 28 & 22 & 20 & 21 & 91 \\
$\mathbf{3}$ & 14 & 22 & 26 & 22 & 84 \\
$\mathbf{4}$ & 20 & 20 & 18 & 21 & 79 \\
$\mathbf{5}$ & 18 & 18 & 20 & 18 & 74 \\
$\mathbf{6}$ & 16 & 15 & 16 & 18 & 65 \\
\hline Total & 123 & 123 & 121 & 126 & $\mathbf{4 9 3}$
\end{tabular}

Table 2. Sample sizes for the data collected after one season of growth. Superscript_p indicates a different sample size for the photo analysis due to mortality in the time between physical measurements and photographing.

\begin{tabular}{l|cccc|c} 
& V. nilotica & S. mellifera & S. laeta & P. juliflora & Total \\
\hline $50 \mathrm{~N}$ & 25 & 25 & 25 & 20 & 95 \\
50 OP & 25 & $25,24^{\mathrm{p}}$ & 25 & $15,14^{\mathrm{p}}$ & $90,88^{\mathrm{p}}$ \\
control & 25 & 26 & 24 & 15 & 90 \\
TO & 25 & 24 & 26 & 15 & 90 \\
\hline Total & 100 & $100,99^{\mathrm{p}}$ & 100 & $65,64^{\mathrm{p}}$ & $365,363^{\mathrm{p}}$
\end{tabular}




\section{RESULTS}

An ideal thorny hedge plant will have high near-ground branch density (as indicated by a high number of stems below $35 \mathrm{~cm}$ and a high edge density value in the photo analysis) and fill its assigned space well (as indicated by a high percent occupancy value in the photo analysis). A line of closely spaced individuals with these attributes will create a formidable barrier to herbivores and thieves.

\section{Nursery Position Comparison}

At the end of their time in the nursery, the mean number of stems below $35 \mathrm{~m}$ was significantly higher for positions 3 (2.41) than position 6 (1.60); $\mathrm{p}=0.06$, Figure 8 .

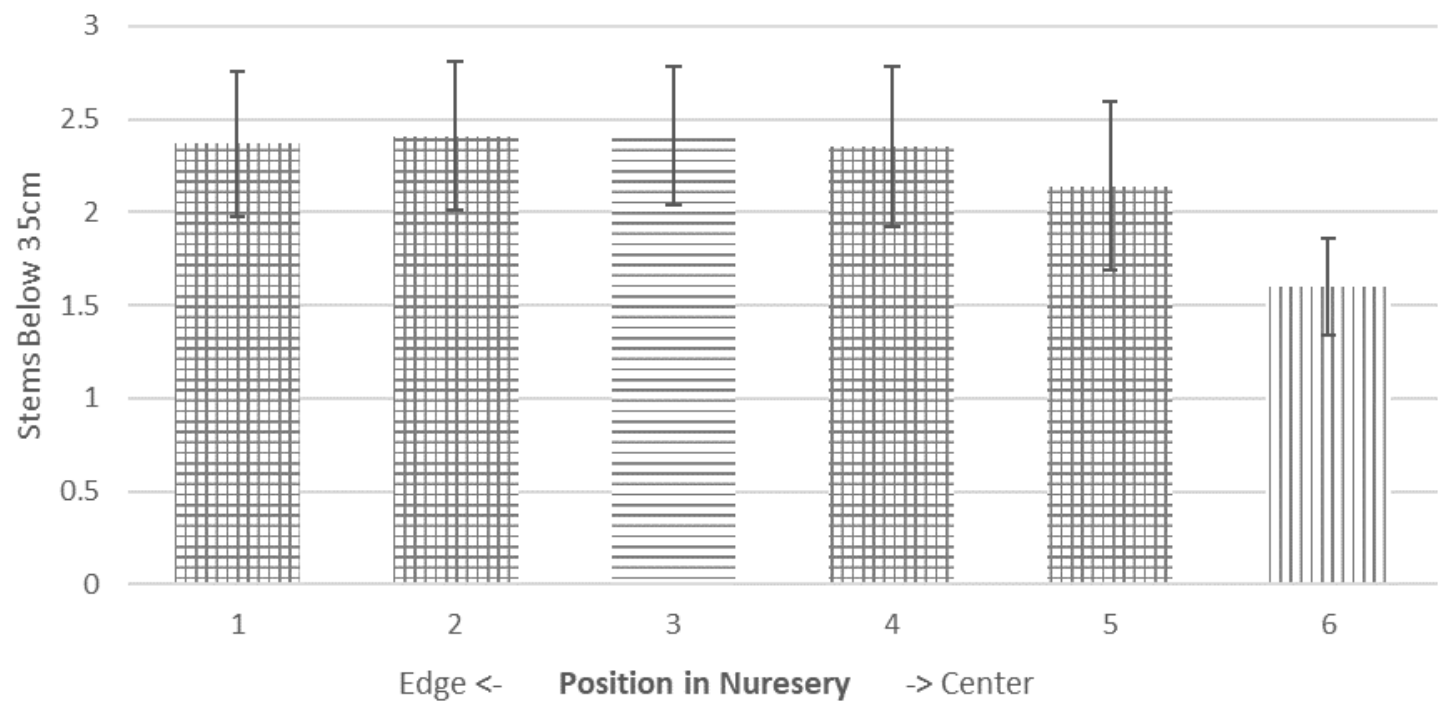

Figure 9. Mean stems below $35 \mathrm{~cm}$ at the time of out-planting, by position in nursery. Position 3 had a significantly higher mean than position $6, \mathrm{p}=0.06$. Position 1 is the nursery edge and position 6 has five plants between it and the nursery edge. Logtransformed data used for statistical tests. Positions not sharing a fill pattern (vertical or horizontal bars) are significantly different. Errors bars indicate the $95 \%$ confidence interval of the mean. 


\section{Interaction Between Variables}

Significant interaction between the variables of Species and Treatment were found only with the Edge Density metric; $p=0.022$, Table 3. As maintenance and upkeep recommendations are often organized by species, treatment effects for all metrics were analyzed by individual species.

Table 3. MANOVA results for the metrics investigated. $\mathrm{DF}=3$ for each variable, 9 for interaction.

\begin{tabular}{rrrrrrr} 
& \multicolumn{2}{c}{ Species } & \multicolumn{2}{c}{ Treatment } & \multicolumn{2}{c}{ Interaction } \\
\cline { 2 - 7 } & \multicolumn{1}{c}{ F ratio } & p-value & F ratio & p-value & F ratio & p-value \\
\hline $\log$ (stems below & 71.421 & $<0.002$ & 0.446 & 0.720 & 1.458 & 0.162 \\
$\mathbf{3 5 c m})$ & & & & & & \\
$\log ($ percent occupancy) & 120.222 & $<0.001$ & 2.623 & 0.051 & 1.831 & 0.062 \\
$\log ($ edge density) & 119.085 & $<0.001$ & 3.249 & 0.022 & 2.189 & 0.022
\end{tabular}

\section{Species Comparison}

Stems Below 35cm - In the Nursery

Just before out-planting, $S$. laeta seedlings had significantly more stems below $35 \mathrm{~cm}$ than all other species, while $P$. juliflora seedlings had significantly fewer stems than all other species; $p<0.001$, Table 4.

Table 4. Mean stems below $35 \mathrm{~cm}$ at the time of out-planting, by species. Logtransformed data used for statistical tests. Species not sharing the same letter are significantly different, $\mathrm{p}<0.001$.

\begin{tabular}{cccc} 
Species & Sig. & Mean & $\begin{array}{c}\text { 95\% Confidence } \\
\text { Interval }\end{array}$ \\
\hline V. nilo & B & 2.2 & $1.9-2.6$ \\
S. mell & B & 2.6 & $2.3-2.9$ \\
S. laet & A & 3.2 & $2.8-3.5$ \\
P. jul & $C$ & 1.0 & $1.0-1.1$
\end{tabular}


Species Comparison - After one Season

After one season of growth, V. nilotica seedlings had significantly more stems below $35 \mathrm{~cm}$ than all other species $(\mathrm{p}<0.002)$, occupied significantly more of their assigned $35 \times 35 \mathrm{~cm}$ space (PLAND metric) than all other species $(\mathrm{p}<0.001)$, and had a significantly higher edge density ratio within their assigned $35 \times 35 \mathrm{~cm}$ space than all other species $(\mathrm{p}<0.001)$. P. juliflora had significantly less stems below $35 \mathrm{~cm}$ than V. nilotica and S. mellifera $(\mathrm{p}<0.002)$. However, there was no significant difference in the number of stems below $35 \mathrm{~cm}$ between $P$. juliflora and S. laeta. P. juliflora occupied significantly less of its assigned space than all other species $(\mathrm{p}<0.001)$ and had significantly lower edge density values than all other species $(p<0.001)$. See Figure 9 for a summary of the above results.

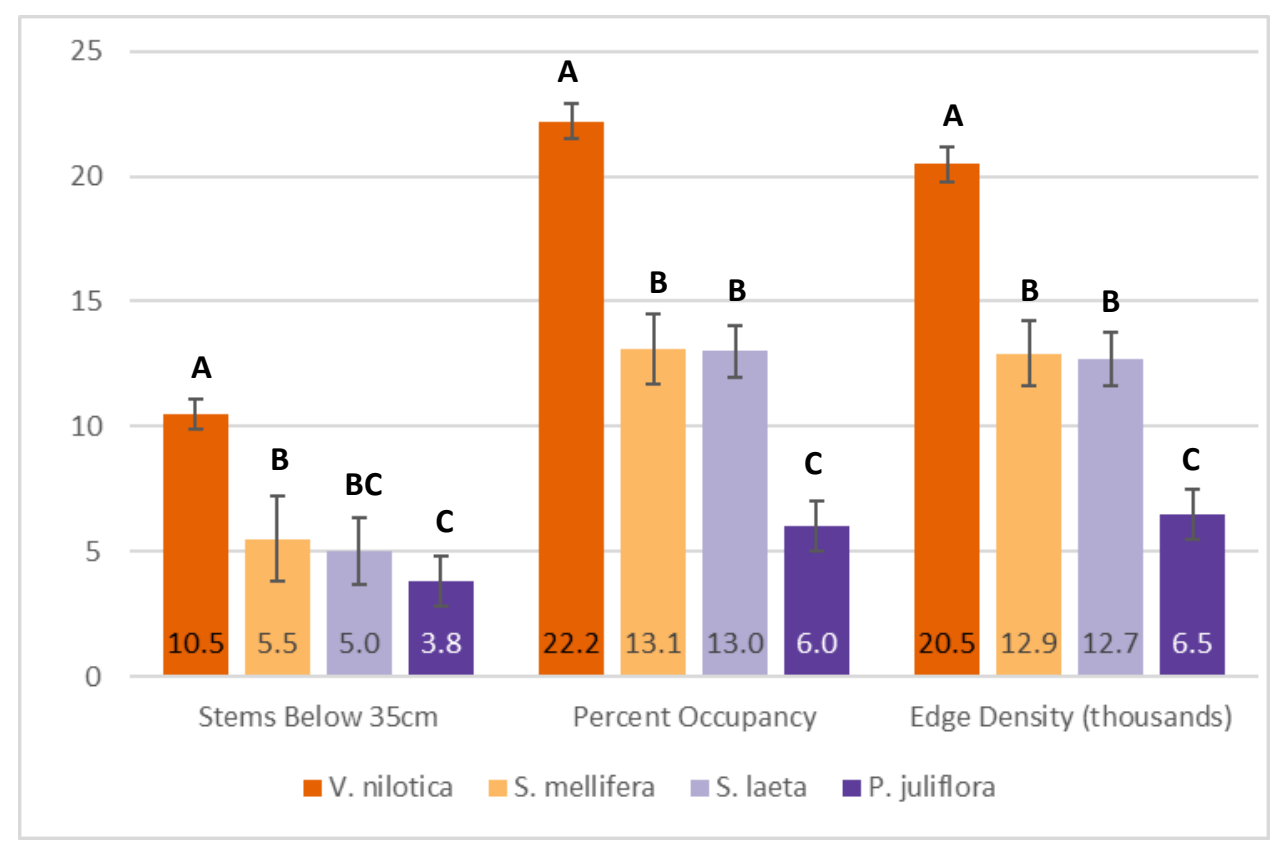

Figure 10. Graph of species comparison results for the three metrics measured. Log-transformed data used for statistical analysis. Error bars indicate the 95\% confidence interval of the mean. Ststistical significance within metrics idicated by letters above error bars. Species sharing letters are not significantly different. 


\section{Pruning Treatments Comparison by Species}

\section{Vachellia nilotica}

No significant difference was found between any of the means of the treatments and the control when considering the number of stems below $35 \mathrm{~cm}$ of $V$. nilotica seedlings. When comparing means of both percent occupancy of their assigned 35x35cm space (PLAND metric) and edge density values for $V$. nilotica seedlings, pruning the seedling to $50 \mathrm{~cm}$ height at out-planting (50 OP) resulted in a significantly lower mean than the control seedlings. $\mathrm{p}=0.03$ for both; Figure 10.

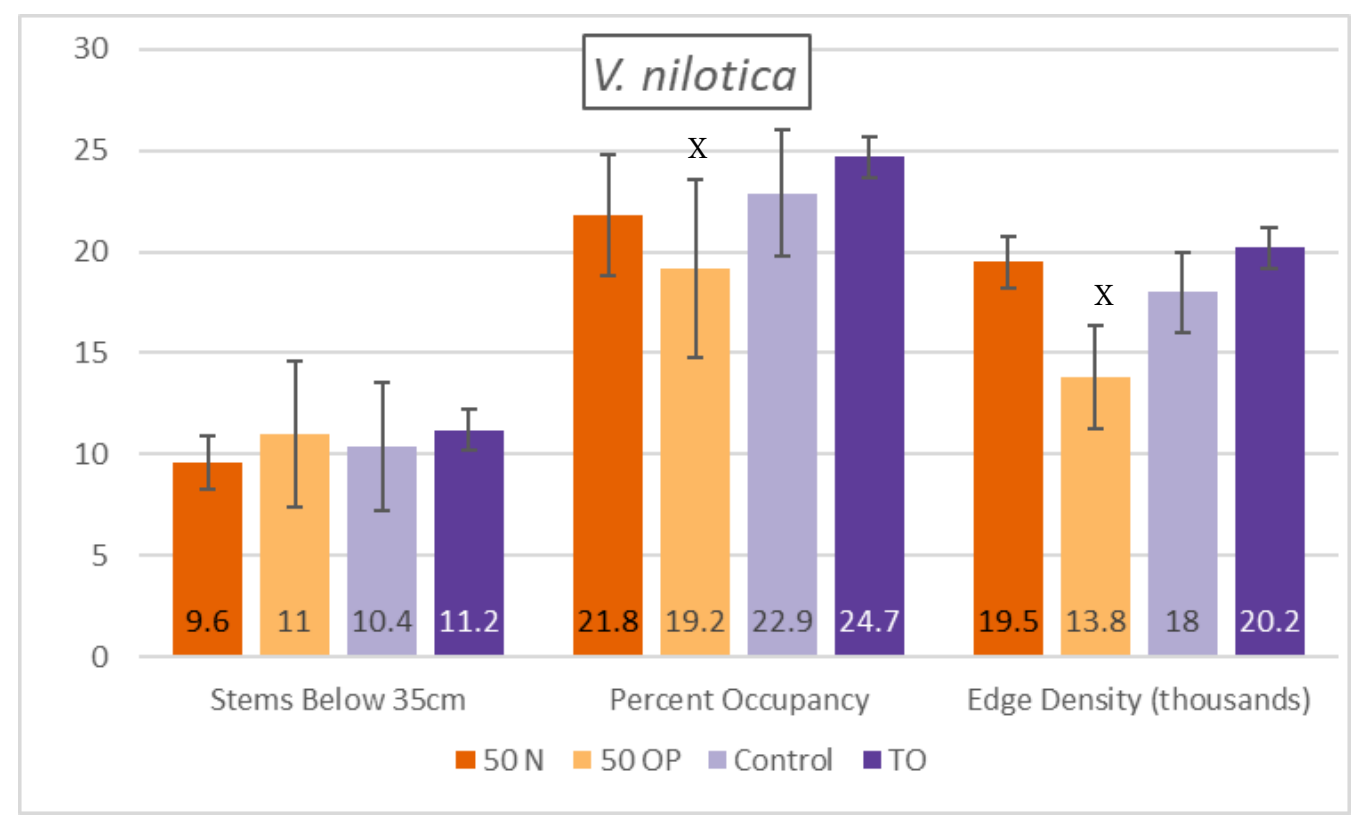

Figure 12. Summary graph of the three metrics comparing treatments within $V$. nilotica seedlings. The treatments are: removing the terminal bud once the plant reaches $50 \mathrm{~cm}$ height in the nursery $(50 \mathrm{~N})$; trimming the main stem to $50 \mathrm{~cm}$ height at out-planting (50 OP); removing the terminal bud at out-planting (TO), plus a control sample (no pruning). Log-transformed data used for statistical analysis. Error bars indicate the $95 \%$ confidence interval of the mean. Significance difference from the Control indicated by an $\mathrm{X}$ above the error bar. 
Senegalia mellifera

No significant difference was found between any of the means of the treatments and the control when considering the number of stems below $35 \mathrm{~cm}$ of $S$. mellifera seedlings. When comparing means of both percent occupancy of their assigned $35 \times 35 \mathrm{~cm}$ space (PLAND metric) and edge density values for $S$. mellifera seedlings, pruning the seedling to $50 \mathrm{~cm}$ height at out-planting (50 $\mathrm{OP})$ resulted in significantly lower values than the control seedlings. $\mathrm{p}=0.04$ for both, Figure 11.

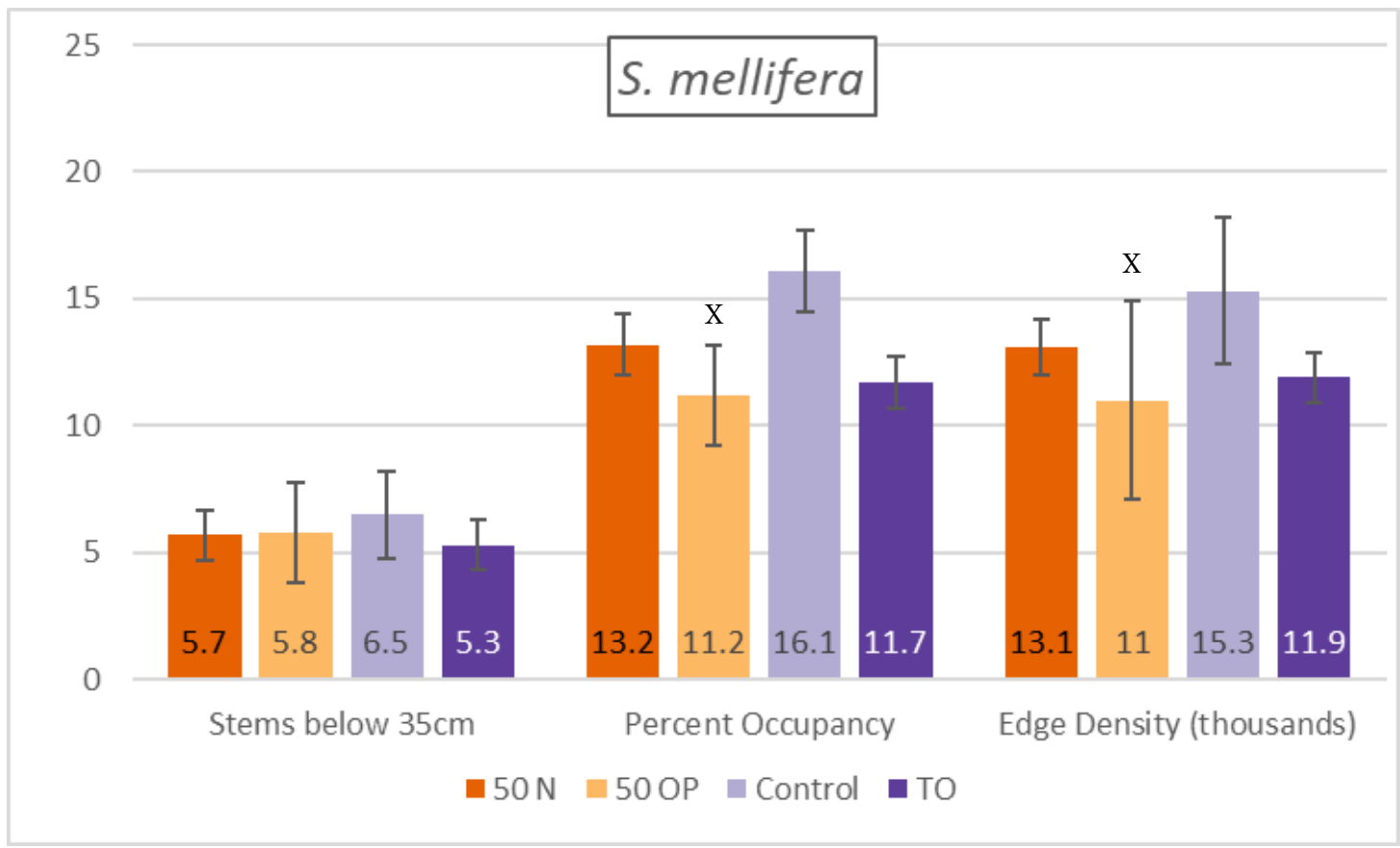

Figure 13. Summary graph of the three metrics comparing treatments within $S$. mellifera seedlings. The treatments are: removing the terminal bud once the plant reaches $50 \mathrm{~cm}$ height in the nursery $(50 \mathrm{~N})$; trimming the main stem to $50 \mathrm{~cm}$ height at out-planting (50 OP); removing the terminal bud at out-planting (TO), plus a control sample (no pruning). Log-transformed data used for statistical analysis. Error bars indicate the $95 \%$ confidence interval of the mean. Significance difference from the Control indicated by an $\mathrm{X}$ above the error bar. 


\section{Senegalia laeta}

For S. laeta, there was no significant difference between the means of any of the treatments and the controls when considering both the number of stems below $35 \mathrm{~cm}$ height and the percent occupancy of their assigned $35 \times 35 \mathrm{~cm}$ space (PLAND metric). However, the mean edge density values for removing the terminal bud at out-planting (TO) were significantly lower than that of the control. $\mathrm{p}=0.04$, Figure 12 .

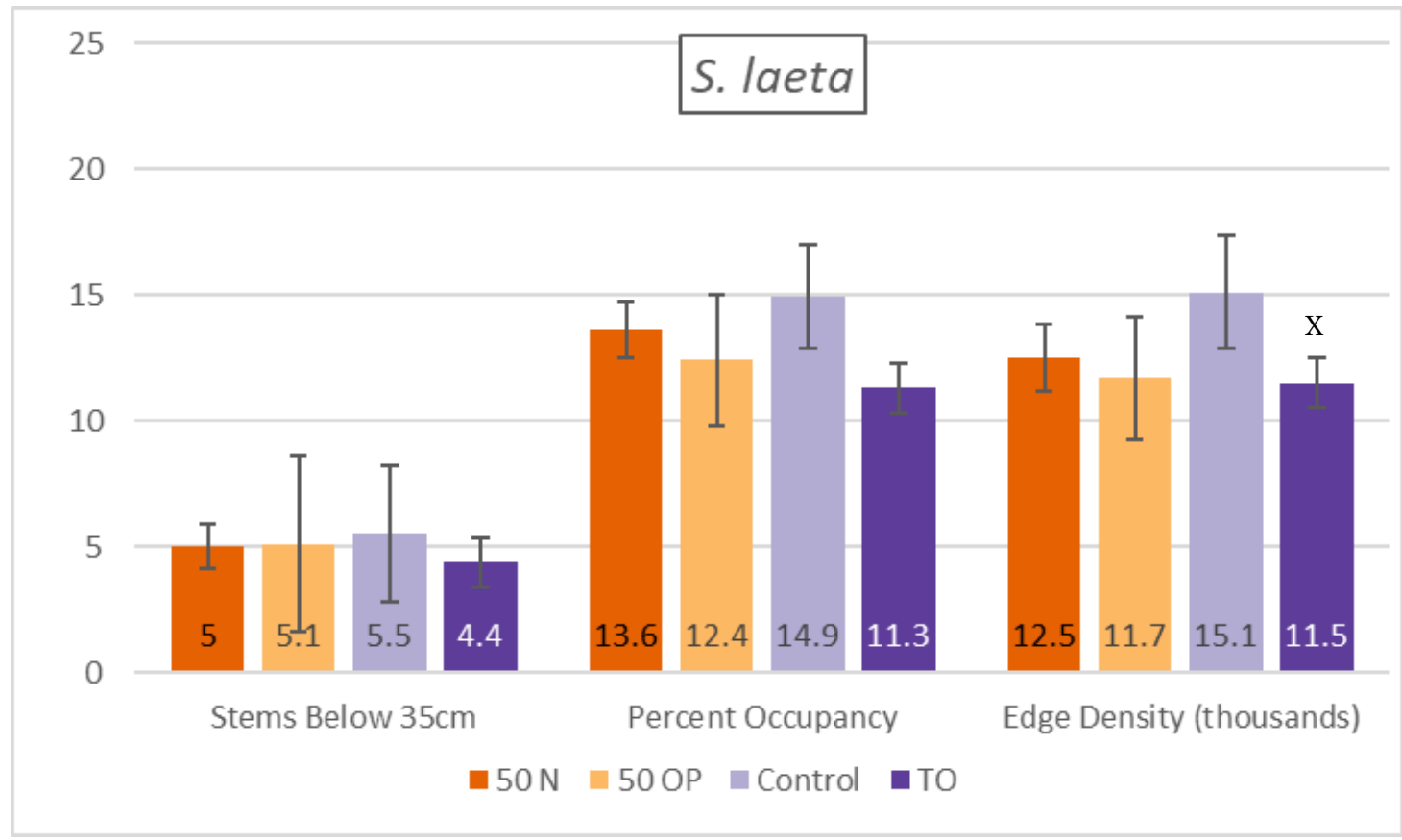

Figure 14. Summary graph of the three metrics comparing treatments within S. laeta seedlings. The treatments are: removing the terminal bud once the plant reaches $50 \mathrm{~cm}$ height in the nursery $(50 \mathrm{~N})$; trimming the main stem to $50 \mathrm{~cm}$ height at out-planting (50 OP); removing the terminal bud at out-planting (TO), plus a control sample (no pruning). Log-transformed data used for statistical analysis. Error bars indicate the $95 \%$ confidence interval of the mean. Significance difference from the Control indicated by an $\mathrm{X}$ above the error bar. 
Prosopis juliflora

No significant differences were found between the means of any of the treatments and the control seedlings of $P$. juliflora for any of the metric measured by this study; Figure 13 .

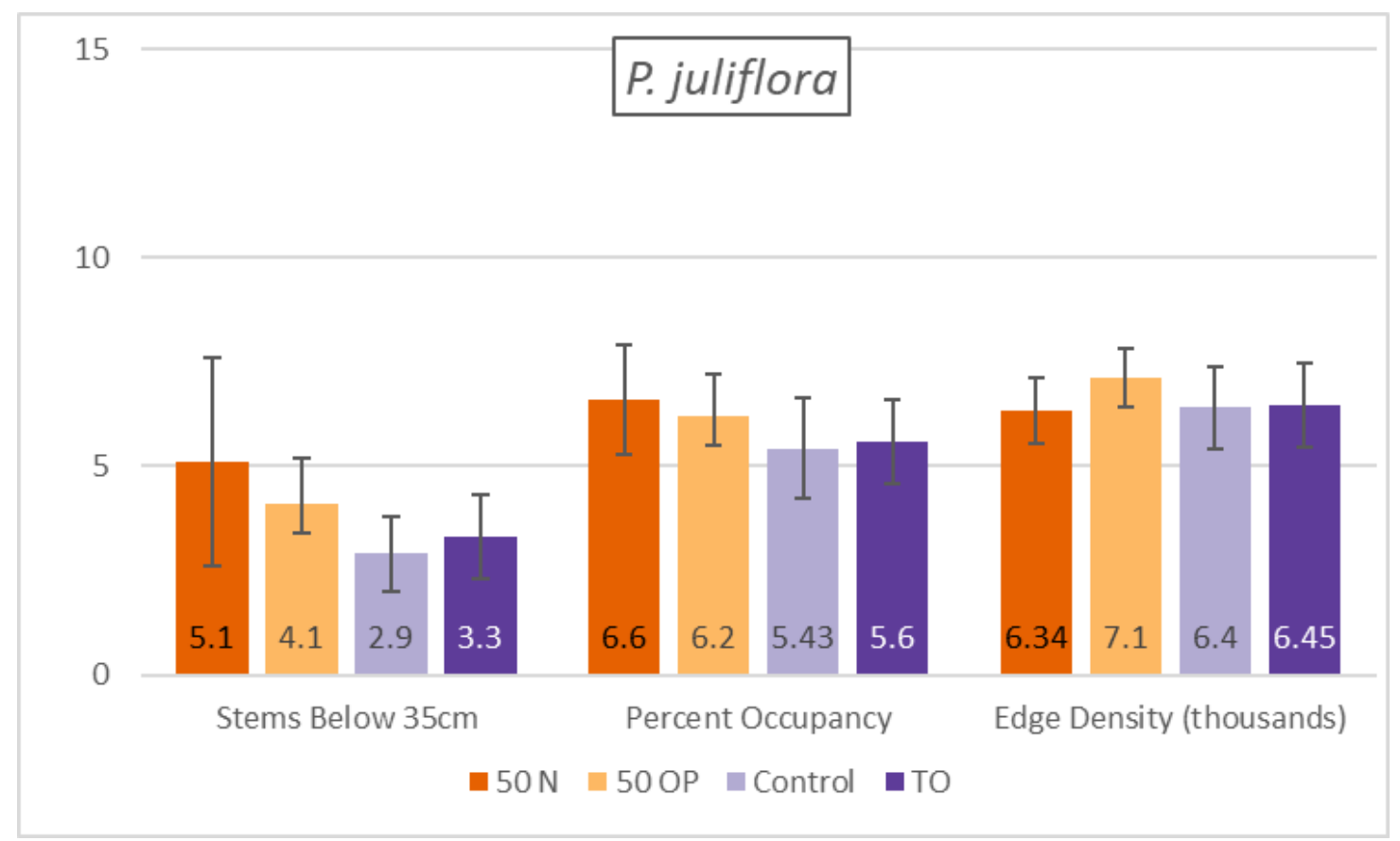

Figure 15. Summary graph of the three metrics comparing treatments within $P$. juliflora seedlings. The treatments are: removing the terminal bud once the plant reaches $50 \mathrm{~cm}$ height in the nursery $(50 \mathrm{~N})$; trimming the main stem to $50 \mathrm{~cm}$ height at out-planting (50 OP); removing the terminal bud at out-planting (TO), plus a control sample (no pruning). Log-transformed data used for statistical analysis. Error bars indicate the $95 \%$ confidence interval of the mean. Significance difference from the Control indicated by an $\mathrm{X}$ above the error bar. 


\section{DISCUSSION}

Since there is little research-based guidance on early pruning, beneficial species, and how to best establish thorny hedges, this study aimed to improve the implementation of thorny hedge technology by investigating two questions. First, which of four highly regarded thorny hedge species: Senegalia laeta, Senegalia mellifera, Vachellia nilotica, and Prosopis juliflora exemplify the desired hedge traits? Second, do any of three commonly recommended early pruning treatments improve a plant's ability to meet the desired criteria? When considering these questions, the ideal thorny hedge plant will have high near-ground branch density (as indicated by a high number of stems below $35 \mathrm{~cm}$ and a high edge density value in the photo analysis) and fill its assigned space well (as indicated by a high percent occupancy value in the photo analysis).

\section{Nursery Position Comparison}

The analysis of stems below $35 \mathrm{~cm}$ height based on position within the tree nursery shows no pattern, suggesting that position within the nursery does not impact the number of primary branches a seedling develops. The high sample size led to significantly different means between positions 3 and 6 which only differ by a fraction of a stem; Figure 9 . While there was statistical significance there is no indication of functional significance.

\section{Species Comparison}

In regards to species, $V$. nilotica appears to be the superior species for thorny hedges given its significantly higher number of stems below $35 \mathrm{~cm}$, higher percent occupancy, and higher edge density values than all other 

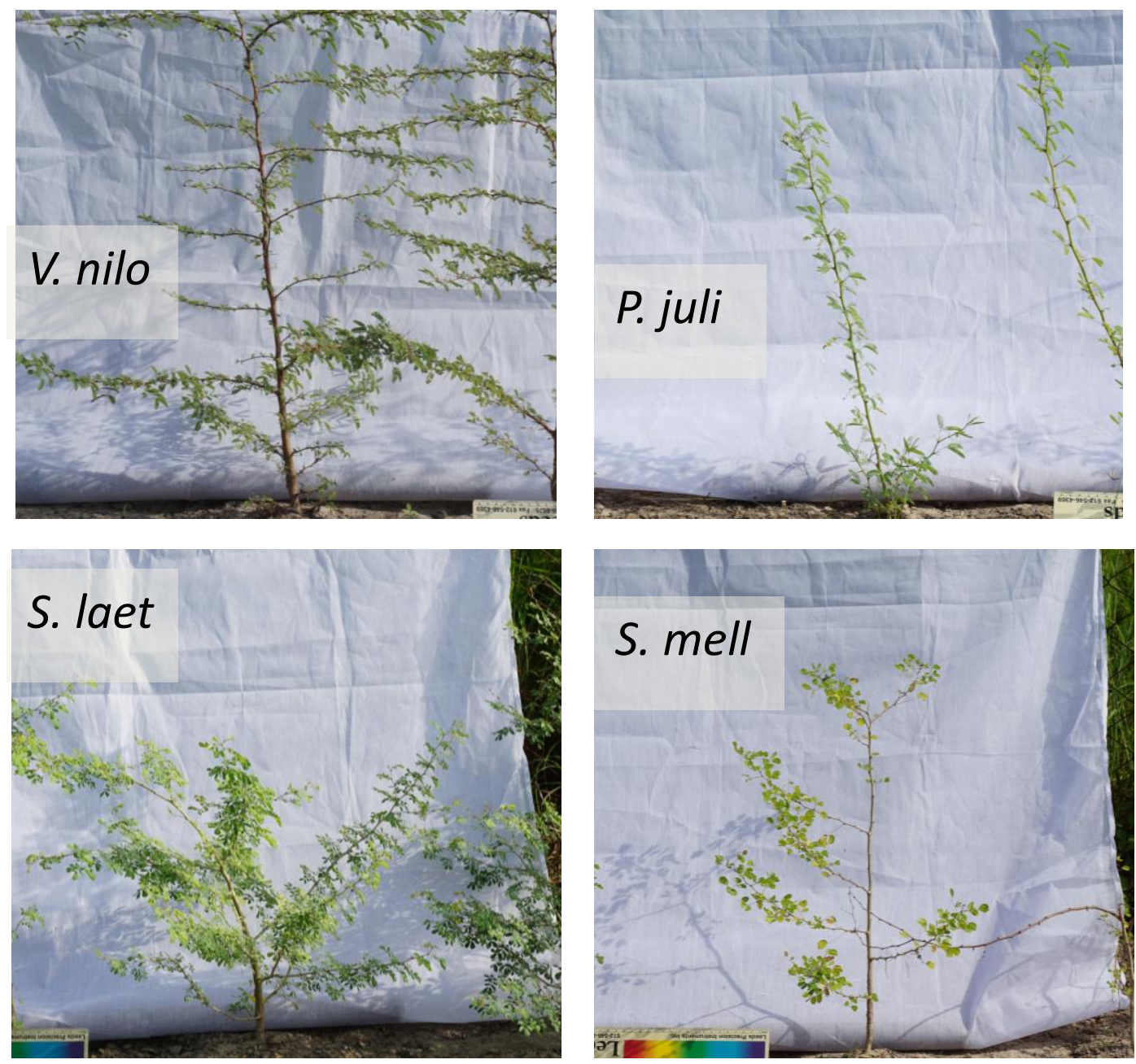

Figure 16. Average individuals of each species from the research fence.

species; Figure 10. While $S$. laeta had the most stems below $35 \mathrm{~cm}$ at the point of out-planting, V. nilotica clearly outperformed in the end. P. juliflora however, had lower values than all the other species in all metrics and appears to be an inferior thorny hedge species; Figure 10, 14. These results are supported by Hien \& Zigani (1987) from Burkina Faso who also found $S$. nilotica to have the highest branch density both below $50 \mathrm{~cm}$ and $30 \mathrm{~cm}$ in a comparison of five thorny hedge species, including P. juliflora. Hien \& Zigani also found that $S$. nilotica had a significantly wider crown than other species at both $50 \mathrm{~cm}$ and $30 \mathrm{~cm}$ height, indicating it was better able to fill horizontal 
space. However, over their two-year study they observed a loss of branches in $V$. nilotica which they felt was due to natural pruning. This was not observed in the current study but this possibility certainly warrants further investigation and emphasizes the importance of longer monitoring periods than what was possible in this study.

Both $S$. laeta and $S$. mellifera had higher values than $P$. juliflora in most metrics, indicating good potential for thorny hedges; Figure 10. These species warrant further investigation and continued utilization for thorny hedges. Although not captured by analyzed metrics, the author noticed that both $S$. laeta and S. mellifera appeared to have higher secondary branching than $V$. nilotica; further investigations would be wise to measure this variable.

\section{Pruning Treatments Comparison}

None of the early pruning treatments significantly increased any of the values of any of the metrics compared to the control plants. The analysis of the treatment effects within individual species showed that pruning seedling to $50 \mathrm{~cm}$ height at out-planting resulted in significantly lower mean percent occupancy and edge density values for $V$. nilotica and $S$. mellifera seedlings; Figures 11-12. No clear explanation for this response could be identified from this study nor the literature on this species. It may be that the amount of biomass lost to this pruning treatment retarded the plants ability to grow or resulted in allotment of resources to other physiologic functions. In the case of $S$. laeta and $P$. juliflora, early pruning treatments did not significantly affect branch density or the ability to fill the assigned space; Figures 13-14. Removing the terminal bud at out-planting did result in a significantly lower edge density value for $S$. laeta seedlings, compared to the control. Given the lack of significance in the other two metrics, it seems unlikely that this 
difference is indicative of a treatment effect; Figure 13. Overall, early pruning did not achieve the desired results of increasing near-ground branch density.

Further study is needed to determine if the apparent lack of treatment effect remains consistent over time. There may be a latent effect of early pruning that was not yet apparent by the time of the last data collection. During my extension activities as a Peace Corps Volunteer in Dialakoto, I observed that nurseries containing $S$. laeta and $S$. mellifera seemed to branch heavily if the nursery had been lightly browsed by livestock; it may be that some threshold damage-level exists to induce heavy branching. However, no evidence could be found in the literature at this time to support this theory. High levels of irradiance (i.e. the full sun conditions that the experimental plants were out-planted into) have been observed to greatly weaken apical dominance and proliferate branching (Andersen 1976, Cline 1996). Therefore, the effects of high irradiation on the experimental plants may have superseded the effects of apical bud removal. If so, once the hedge is grown and a lower percent of the canopy receives full sun, pruning and the release of apical dominance at the branch level may have a greater impact on lateral bud release.

\section{Implications}

The results of this study suggest that the technology of thorny hedges may be implemented more easily than current extension practices suggest. Well maintained and protected spaces in which to house gardens and tree nurseries are at a premium in West Africa and farmers prefer to create wide, tightly packed tree nurseries for space efficiency. It was speculated that plants grown in the center of such nurseries would allocate more resources towards vertical growth than horizontal branching, reducing their effectiveness for 
thorny hedges. The results suggest farmers may utilize dense tree nurseries in their limited protected spaces without detrimental effects.

Many agroforestry extension organizations encourage farmers to prune their thorny hedge plants in the nursery or at out-planting to induce early branching. However, the recommended timing of this task coincides with heavy demands for farm labor thereby limiting implementation by farmers. These results suggest that early pruning does not significantly increase nearground branch density on thorny hedge plants, at least within the first season. Certain treatments can even have a negative effect, in the case of $V$. nilotica and $S$. mellifera. Pruning early in a thorny hedge plant's life appears not to be necessary nor beneficial. Not pruning during the first season and allowing the plants to accumulate biomass may increase their chances of surviving their first dry season when mortality is highest. Therefore, farmers need not divert limit labor-hours to early pruning.

\section{Future Research}

To be clear, these results don't imply that pruning of thorny hedges is unnecessary. There is no doubt that pruning is eventually necessary to increase branching and create a dense barrier. These results simply suggest that early pruning, in the nursery or at out-planting, does not immediately impact near-ground branch density. If any of these species have determinant growth, pruning effects may be delayed until the next season. Although I could not find any information on whether these species are determinant or indeterminant growers, at the minimum one additional year of data would be needed to more definitively state the effects of early pruning. Therefore, further studies should explore which frequency and methods of pruning are 
most effective at forming a dense near-ground canopy, particularly when hedges are further along in their formation.

It should be noted that these results come from a single experimental site exposed to full sun and with sandy soils. Sites with greater shading or different soil textures may yield different results. The small collection of research on thorny hedges would benefit from additional research replicating these treatments in sites with differing conditions. Longer term evaluation of the results would be beneficial as well, especially once the individual canopies meet. After one season of growth, a barrier had yet to form and the effectiveness of the individuals at forming a collective hedge is being predicted here, not measured.

On a more basic level, the variables which determine the effectiveness of a thorny hedge as a barrier are being assumed. I found no research which has investigated the best metrics for thorny hedge efficacy. Basic questions such as: how dense do the branches need to be, how small a gap can goats or sheep penetrate, and do other characteristics beyond a plants ability to fill space (such as thorn morphology) impact effectiveness, still need to be answered. In Mali, Levasseur et al. (2009) found that the adoption of thorny hedges was dependent largely on knowledge of how to implement the technique and the sharing of that knowledge by extension agents. I have heard mention of and seen citations of studies relating to thorny hedges by NGOs or government agencies, but could not locate the vast majority of them. Thus, there is a need to make these materials publicly available so that extension agencies can be well informed and transfer techniques with demonstrated effectiveness on to farmers. 


\section{Conclusions}

In conclusion, these findings suggest that farmers in West Africa:

- Can grow thorny hedge seedlings in dense, space efficient nurseries

- Should include Vachellia nilotica in their thorny hedges

- Should create mixed species hedges which include Seneglaia laeta and Senegalia mellifera, given the downfalls of monocultures

- Need not incorporate Prosopis juliflora into hedges under similar conditions to the experiment

- May not need to perform early pruning in the nursery or at outplanting to increase near-ground branch density

Finally, there is a significant need for further research on the construction and maintenance of thorny hedges, and the broader sharing of non-academic research results (from NGOs and government agencies) regarding thorny hedges. 


\section{WORKS CITED}

Adepetu, J., H. Nabhan, and A. Osinubi. 1996. Simple soil, water and plant testing techniques for soil resource management. Proceedings of a training course held in Ibadan, Nigeria:16-27.

Andersen, A. S. 1976. Regulation of apical dominance by ethephon, irradiance and CO2. Physiologia Plantarum 37:303-308.

Animal Science, Dep. o. 1999. Sahelian Goat. Breeds of Livestock. Oklahoma State University, Oklahoma, USA.

ANSD. 2015. Regional Report of Statistics and Demography for Tambacounda. Ministere de L'economie, des Finances et du Plan, Tambacounda, Senegal.

Arbonnier, M. 2004. Trees, shrubs and lianas of West African dry zones. MARGRAF Publishers GMBH Wageningon, The Netherlands.

Archibald, S., and W. J. Bond. 2003. Growing tall vs growing wide: tree architecture and allometry of Acacia karroo in forest, savanna, and arid environments. Oikos 102:3-14.

Ayuk, E. 1994. On measuring the economic importance of live hedges to household economies in the Central plateau of Burkina Faso. Pages 9-14 in Rockefeller Foundation Biennial Social Science Fellows meeting. Addis Ababa, Ethiopia.

Ayuk, E. T. 1997. Adoption of agroforestry technology: the case of live hedges in the Central Plateau of Burkina Faso. Agricultural systems 54:189-206.

Ba, C. 1986. Les Peuls du Senegal. Etude geographique, Les Nouvelles Editions Africaines, Dakar.

Bannister, N. R., and T. A. Watt. 1995. Effects of Cutting on the Growth ofCrataegus monogyna(Hawthorn) in Hedges. Journal of Environmental Management 45:395-410.

Bassett, T. J. 1988. The political ecology of Peasant-Herder conflicts in the northern ivory coast. Annals of the association of American geographers 78:453-472.

Batjes, N. 2008. Soil parameter estimates for Senegal and Gambia derived from SOTER and WISE (SOTWIS-Senegal, ver. 1.0). ISRIC - World Soil Information, Wageningen, Netherlands 
Blench, R. 1984. Conflict and Co-operation Fulbe Relations with the Mambila and Samba People of Southern Adamawa. Cambridge Anthropology:42-57.

Bond, W. J., K. A. Smythe, and D. A. Balfour. 2001. Acacia species turnover in space and time in an African savanna. Journal of Biogeography 28:117-128.

Breusers, M., S. Nederlof, and T. Van Rheenen. 1998. Conflict or symbiosis? Disentangling farmer-herdsman relations: the Mossi and Fulbe of the Central Plateau, Burkina Faso. The Journal of Modern African Studies 36:357-380.

Butterfield, R., and N. Niamey. 1996. Prosopis in Sahelian forestry projects: A case study from Niger. Prosopis: Semiarid Fuelwood and Forage Tree. Building Consensus for the Disenfranchised. Center Semi-Arid Forest Resources Publ. Kingsville, TX. FROM GRASSLANDS TO ALPINE ENVIRONMENTS 250.

CIA. 2017. SENEGAL. The World Factbook. Central Intelligence Agency, Web.

Cline, M. G. 1994. The role of hormones in apical dominance. New approaches to an old problem in plant development. Physiologia Plantarum 90:230-237.

Cline, M. G. 1996. Exogenous auxin effects on lateral bud outgrowth in decapitated shoots. Annals of Botany 78:255-266.

Cline, M. 1997. Concepts and terminology of apical dominance. American Journal of Botony 84:1064.

Cole, T. J. 1980. Hedge for Canadian Gardeners. Page 33 in O. R. Station, editor. Agriculture Canada.

Cooper, S. M., and N. Owen-Smith. 1986. Effects of plant spinescence on large mammalian herbivores. Oecologia 68:446-455.

Dangerfield, J., and B. Modukanele. 1996. Over compensation by Acacia erubescens in response to simulated browsing. Journal of Tropical Ecology 12:905-908.

Davidheiser, M., and A. M. Luna. 2008. From complementarity to conflict: A historical analysis of farmer-Fulbe relations in West Africa. African Journal on Conflict Resolution 8:77-103.

Djitte, C. 2015. Personal Communication to A. Devens.

Drame, B. 2016. Personal Communication to A. Devens.

ESRI. 2015. ArcView GIS. Environmental Systems Research Institute, Inc., Redlands, CA. 
Forman, R. T., and J. Baudry. 1984. Hedgerows and hedgerow networks in landscape ecology. Environmental management 8:495-510.

Fornara, D., and J. Du Toit. 2007. Browsing lawns? Responses of Acacia nigrescens to ungulate browsing in an African savanna. Ecology 88:200-209. Gowda, J. H. 1996. Spines of Acacia tortilis: What Do They Defend and How? Oikos 77:279-284.

Henderson, L. 1983. Barrier plants in South Africa. Bothalia 14:635-639.

Hien, F., and G. Zigani. 1987. Haie vive: un modèle de l'integration de l'arbre au système d'exploitation agricole et pastorale.

Howes, F. 1946. Fence and barrier plants in warm climates. Kew Bulletin 1:5187.

Hussein, K., J. Sumberg, and D. Seddon. 1999. Increasing violent conflict between herders and farmers in Africa: claims and evidence. Development policy review 17:397-418.

Hyslop, M. 2017. Personal Communication to A. Devens.

Kelley, M., J. Chahin, J. Mattison, S. Smith, and A. Khong. . 2016. Live Fencing Manual: Sustainable Protection for Senegal. 2 edition. United States Peace Corps Senegal, Dakar, Senegal.

Kelly, V., B. Diagana, T. Reardon, M. Gaye, and E. Crawford. 1996. Cash crop and foodgrain productivity in Senegal: historical view, new survey evidence, and policy implications. Michigan State University, East Lansing, MI.

Kimball, S., and P. Mattis. 2015. GNU Image Manipulation Software (GIMP). GIMP.

Landais E., P. Lhoste, And H. Guerin. 1991. Systèmes d'élevage et transferts de fertilité. Pages 219-270 in P. F. M. d. l. C. e. d. D. Centre de Cooperation Internationale en Recherche Agronomique pour le Developpement, Paris (France). Savanes d'Afrique, terres fertiles? Comment produire plus et de facon durable en zone de savanes au sud du Sahara, Paris.

Levasseur, V., M. Djimdé, and A. Olivier. 2004. Live fences in Ségou, Mali : an evaluation by their early users. Agroforestry Systems 60:131-136.

Levasseur, V., A. Olivier, and S. Franzel. 2009. Factors affecting adoption of the improved living hedge in Mali. Cahiers Agricultures 18:350-355.

Lindsey, P. A., C. L. Masterson, A. L. Beck, and S. Romañach. 2012.

Ecological, social and financial issues related to fencing as a conservation tool in Africa. Pages 215-234 Fencing for conservation. Springer. 
Louppe, D., and H. Yossi. 1999. Les Haies-vives défensives en Afrique de l'Ouest Sèche et Subhumide (Bilan des connaissances).

Madany, M. 1991. Living fences: Somali farmers adopt an agroforestry technology. Agroforestry Today 3:4-7.

Maertens, M. 2009. Trade, standards, and poverty: Evidence from Senegal. World Development 37:161.

Magistro, J. 1997. The ecology of food security in the northern Senegal wetlands. The Ecology of Practice: Studies of Food Crop Production in SubSaharan West Africa. Food and Nutrition in History and Anthropology 12:97135 .

Mahat, T. B. S. 1993. Agroforestry Training Course Module for Bangladesh. Proceedings of the Workshop Held at the Bangladesh Agricultural Research Council (Feb 27 - Mar 4, 1993). BARC - Winrock International, Dhaka, Bangladesh.

Martin, F. 1991. The living fence: its role on the small farm. ECHO, North Fort Meyers, USA.

Massaly, F., Y. Boye, and A. Sadio. 2014. Gardening in Senegal. Peace Corps Senegal, Dakar, Senegal

Matarasso, M., V. D. Nguyen, and D. T. T. Huyen. 2003. The Agroforestry Field Guide: A Tool For Community Based Environmental Education. World Wildlife Fund.

McCown, R., G. Haaland, and C. de Haan. 1979. The interaction between cultivation and livestock production in semi-arid Africa. Pages 297-332 Agriculture in semi-arid environments. Springer.

McGarigal, K. 2015. FRAGSTATS. LandEco Consulting, University of Massachusetts, Amherst.

Miehe, S., J. Kluge, H. Von Wehrden, and V. Retzer. 2010. Long-term degradation of Sahelian rangeland detected by 27 years of field study in Senegal. Journal of Applied Ecology 47:692-700.

Milton, S. J. 1991. Plant spinescence in arid southern Africa: does moisture mediate selection by mammals? Oecologia 87:279-287.

Ogada, M. O., R. Woodroffe, N. O. Oguge, and L. G. Frank. 2003. Limiting depredation by African carnivores: the role of livestock husbandry. Conservation biology 17:1521-1530.

Ouangraoua, H. 1988. Protecting the garden. IDRC reports, v. 17, no. 4. 
Pineau, W., and A.-B. Tsatsu, editors. 2010. Agroforestry Guide: Experiences from farmer trainings in Ghana. Pro-Natua International, Paris, France.

Ramón-Laca, L. 2015. Hedges and hedgerows: traditional elements of the rural landscape in the Iberian Peninsula. Studies in the History of Gardens \& Designed Landscapes 35:21-24.

RHS. 2015. Acacia: pruning. Learn about pruning with expert advice from the RHS. Royal Horticultural Society, London.

Rocheleau, D., F. Weber, and A. Field-Juma. 1988. Agroforestry in dryland Africa.

Sane, A. 2016. Personal Communication to A. Devens.

Sanogo, D., Y. K. Dia, E. Ayuk, and R. Pontanier. 1999. Adoption de la haie vive dans le bassin arachidier du Sénégal. Séminaire international sur la jachère en Afrique Tropicale, rôles, aménagements, alternatives, Dakar (Sénégal), 13-16 avril 1999.

Schulze, E.-D., G. Gebauer, H. Ziegler, and O. Lange. 1991. Estimates of nitrogen fixation by trees on an aridity gradient in Namibia. Oecologia 88:451455 .

Seignobos, C. 1980. Des fortifications végétales dans la zone soudanosahélienne (Tchad et Nord-Cameroun).

Sharma, P., and U. Devi. 2013. Ethnobotanical uses of biofencing plants in Himachal Pradesh, Northwest Himalaya. Pak J Biol Sci 16:1957-1963.

Sidibe, D. D., C.; Constant, A.; Blass, C. 2012. The Peace Corps-Senegal Agroforestry Manual. 2 edition. United States Peace Corps Senegal, Dakar, Senegal.

Steavenson, H. A. 1946. Multiflora rose for farm hedges. The Journal of Wildlife Management 10:227-234.

Steeves, T. A., and I. M. Sussex. 1989. Patterns in plant development. Cambridge University Press.

Stenning, D. J. 1959. Savannah nomads: a study of the Wodaabe pastoral Fulani of Western Bornu Province Northern region, Nigeria. LIT Verlag Münster.

Stoorvogel, J., N. Van Breemen, and B. Jassen. 1997. The nutrient input by Harmattan dust to a forest ecosystem in Cote d'Ivoire, Africa. Biogeochemistry 37:145-157. 
Suzanne, E. M., C. H. C. Marjolein, J. J. Ross, K. Santi, and A. B. Christine. 2005. Auxin Dynamics after Decapitation Are Not Correlated with the Initial Growth of Axillary Buds. Plant Physiology 138:1665-1672.

Tappan, G. G., M. Sall, E. C. Wood, and M. Cushing. 2004. Ecoregions and land cover trends in Senegal. Journal of arid environments 59:427-462.

Tengnäs, B. 1994. Agroforestry extension manual for Kenya. World Agroforestry Centre.

Thuo, M., B. E. Bravo-Ureta, I. Hathie, and P. Obeng-Asiedu. 2011. Adoption of chemical fertilizer by smallholder farmers in the peanut basin of Senegal. African Journal of Agricultural and Resource Economics 6.

Treasury, Dept. o. 2015. TREASURY REPORTING RATES OF EXCHANGE AS OF DECEMBER 31, 2014. in D. o. T.-B. o. F. Service, editor. Finance and Shared Serivices Division, Washington D.C.

Future, T. f. t. 2008. Taking Action, Reaching Out. 3rd edition. Trees For the Future, Silver Springs, Maryland, USA.

Toulmin, C. 1983. Herders and Farmers or Farmer-herders and Herderfarmers? Overseas Development Institute Pastoral Network Paper Paper 15d. London, UK.

Vesey-FitzGerald, D. F. 1973. Animal Impact on Vegetation and Plant Succession in Lake Manyara National Park, Tanzania. Oikos 24:314-324.

Wickens, G. E. 1995. Role of Acacia species in the rural economy of dry Africa and the Near East. Food \& Agriculture Org.

Yossi, H., B. Kaya, C. Traoré, A. Niang, I. Butare, V. Levasseur, and D. Sanogo. 2006. Les haies vives au Sahel: état des connaissances et recommandations pour la recherche et le développement. World Agroforestry Centre.

Young, A. 1989. Agroforestry for Soil Conservation.in ICRAF, editor. BPCC Wheatons Ltd., Exeter, UK. 


\section{Appendix A - Layout of the Research Fence}

Figure A1. The research fence ran a continuous length but has been parceled for display purposes. Each block contains five individuals. Ends sharing a number abut each other in the actual fence. Plants were spaced $35 \mathrm{~cm}$ within row and $50 \mathrm{~cm}$ in from the chain-link fence. The treatments are: removing the terminal bud once the plant reaches $50 \mathrm{~cm}$ height in the nursery $(50 \mathrm{~N})$; trimming the main stem to $50 \mathrm{~cm}$ height at out-planting $(50 \mathrm{OP})$; removing the terminal bud at out-planting (TO), plus a control sample (no pruning).

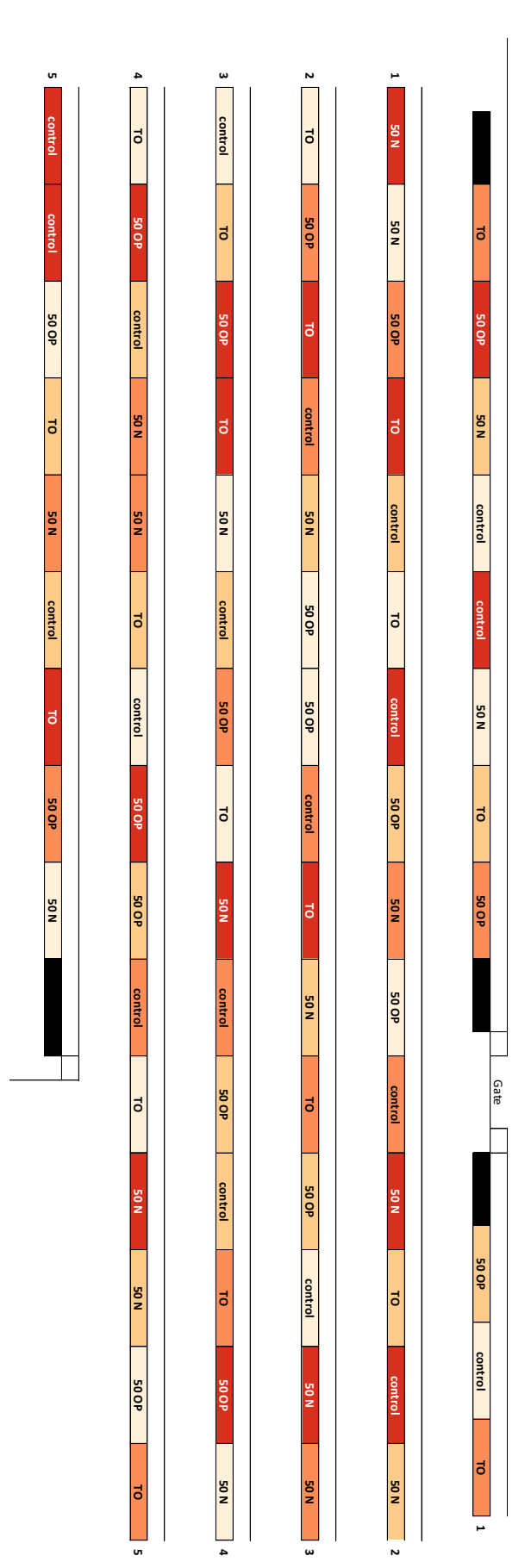




\section{Appendix B - Copyright Documentation}

Figures $1 \& 6$ - Photographs used with permission; Figure B1.

23 July 2017

I, Gwendolyn Jacobson, give permission to Aric Devens to use my personal photography in his Master's

Thesis at Michigan Technological University.

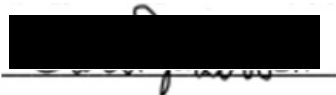

Figure B1. Letter from Gwen Jacobson providing permission to use her personal photography.

Figure 2 - Photographs taken from the public domain; published by U.S. Peace Corps, U.S. Department of State.

Kelley, M., J. Chahin, J. Mattison, S. Smith, and A. Khong. 2016. Live Fencing Manual: Sustainable Protection for Senegal. 2nd edition. United States Peace Corps Senegal, Dakar, Senegal. 


\section{Appendix C - Steps Used In Processing the Photo Data}

Create and fill grid in GIMP 2.8 program:

1. In your image $>$ zoom in on the ruler in the photo and use the measurement tool to find the pixel/cm for each image

2. From the menu tabs $>$ Layer $>$ New Layer

a. Name = "Grid"

b. Set width and height as desired based on pixel $/ \mathrm{cm}$

3. In the "Grid" layer $>$ From the menu tabs $>$ Filters $>$ Render $>$ Pattern $>$ Grid

a. In the grid menu $>$ Spacing $=$ pixel $/ \mathrm{cm}$

4. Align grid as desired over image

5. Use Bucket Fill tool to fill grid.

6. Create a new image the same size as your grid

7. Drag the "Grid" layer to the new image

8. In Layers window $>$ right click "Grid" $>$ remove alpha channel

9. In menu tabs $>$ Image $>$ Mode $>$ Indexed $>$ Use black and White (1-bit)

10. Now you must remove the grid lines $>$ use the Foreground Select tool

a. Roughly outline plant $>$ left click

b. SHIFT + left click outside your outline to invert selection

c. Use Bucket Fill to make the entire background white, removing the grid lines

11.In menu tabs $>$ File $>$ Export as... $>$ Tiff format

Geolocate Tiffs in ArcGis for use in FRAGSTATS

1. Import Tiff file

2. Use tool $>$ Project $>$ select NON geographic coordinate system

3. Or use an iteration to complete this task for large numbers (email awdevens@mtu.edu and I can share it)

FRAGSTATS would not accept the GeoTIffs I created via this method. So....

Convert all GeoTiffs to .img format in Erdas Imagine. FRAGSTATS accepted these without issue.

Analyze photo data in FRAGSTATS 